\title{
Responsible Investing for Food System Sustainability: \\ A Review of Current Practice in Australia
}

\author{
Christine Parker, ${ }^{*}$ Ella Robinson, ${ }^{\dagger}$ Rachel Carey,${ }^{\ddagger}$ Laura Boehm, ${ }^{\S}$ and Gary Sacks ${ }^{* *}$
}

In press in Environmental and Planning Law Journal (2021), Vol 38(3)

Correspondence: Professor Christine Parker; christine.parker@unimelb.edu.au; Melbourne Law School, The University of Melbourne, 3010, Parkville, VIC, Australia. Ph. 0432944330

\section{Conflicts of interest}

The authors declare that the research was conducted in the absence of any commercial or financial relationships that could be construed as a potential conflict of interest.

\begin{abstract}
Authors' contributions
$\mathrm{CP}, \mathrm{RC}, \mathrm{ER}$ and GS were involved in the conceptualisation and design of the study. ER and LB conducted data collection. LB and CP conducted data analysis. CP, ER and RC cross-checked data analysis. CP and ER drafted the manuscript. All authors reviewed and edited the manuscript.
\end{abstract}

\section{Funding}

$\mathrm{CP}$ and $\mathrm{RC}$ receive funding from the Melbourne Sustainable Society Institute, the University of Melbourne. $\mathrm{RC}$ receives funding from a Lord Mayor's Charitable Foundation initiative grant. ER is funded through an Australian Government Research Training Program (RTP) Scholarship. GS is supported by a Heart Foundation Future Leader Fellowship (102035) from the National Heart Foundation of Australia. He is also a researcher within National Health and Medical Research Council (NHMRC) Centres for Research Excellence entitled Reducing Salt Intake Using Food Policy Interventions (APP1117300) and a Centre of Research Excellence in Food Retail Environments for Health (RE-FRESH) (APP1152968). The funders had no role in the design of the study, data collection, analysis, interpretations of the data or in writing the manuscript.

\section{Acknowledgments}

We acknowledge the assistance of Larissa Barrows with background literature review, Adam Carey and Deborah Hambleton for helpful discussions, and Ken Zhunwye Kiat and the Melbourne Law School Academic Research Service for help with references.

\footnotetext{
* christine.parker@unimelb.edu.au, Melbourne Law School, The University of Melbourne, 3010, Parkville, VIC, Australia. † ella.robinson@deakin.edu.au, Institute for Health Transformation, Global Obesity Centre (GLOBE), Deakin University, 221 Burwood Highway, Burwood, Victoria 3125 Australia.

* rachel.carey@unimelb.edu.au, School of Agriculture and Food, The University of Melbourne, 3010, Parkville, VIC, Australia.

§laura.boehm@unimelb.edu.au, Melbourne Law School, The University of Melbourne, 3010, Parkville, VIC, Australia.

** gary.sacks@ deakin.edu.au, Institute for Health Transformation, Global Obesity Centre (GLOBE), Deakin University, 221

Burwood Highway, Burwood, Victoria 3125 Australia.
} 
Key words: Responsible investment, sustainable finance, sustainable food systems, climate change, biodiversity loss

\title{
Responsible Investing for Food System Sustainability: A Review of Current Practice in Australia
}

\begin{abstract}
This study investigates what role if any responsible investment by the finance sector is playing in promoting sustainable food systems in Australia. We report the findings of a preliminary desktop review of environmental, social and governance reporting by 35 of the most prominent responsible investment funds managers in Australia. Only one responsible investment fund had a comprehensive policy in relation to food system themes and 16 did not specifically mention the environmental, social and governance issues raised by food systems at all. Some addressed labour rights and intensive animal agriculture issues in the food system, and a few mentioned the climate change, biodiversity loss and water impacts offood. We conclude that a more comprehensive and holistic approach to consideration of sustainable food systems in responsible investment is required to meet the goals set by the Paris Agreement, Sustainable Development Goals and other environmental and human rights frameworks
\end{abstract}




\section{INTRODUCTION}

The term 'food systems' refers to 'the path that food travels from field or farm to fork' ${ }^{1}$ It encompasses all 'the growing, harvesting, processing, packaging, transporting, marketing, consuming, and disposing of food' as well as 'all the inputs needed and outputs generated along the way', and 'the mix of social, political, economic, and environmental factors that influence and are influenced by food supply pathways'. ${ }^{2}$ The food system as a whole is a major driver of climate change, biodiversity loss, depletion of freshwater resources and pollution of waterways. $^{3}$ According to the Intergovernmental Panel on Climate Change (IPCC) between $21 \%$ and $37 \%$ of total greenhouse gas emissions are attributable to the food system. ${ }^{4}$ In particular land use change for agriculture is a significant driver of the climate crisis and must be stopped and reversed in order to meet the Paris Agreement target of no more than 1.5 or 2 degrees warming. ${ }^{5}$ Land clearing for agriculture is a significant driver of deforestation and biodiversity loss globally. ${ }^{6}$ Land clearing for food production also plays a role in the transfer of zoonotic diseases from wild to domesticated animals and to humans, such as likely occurred in the COVID-19 pandemic, by forcing wild animals into closer contact with production animals and humans. ${ }^{7}$

\footnotetext{
${ }^{1}$ Sharon Friel, Climate Change and the People's Health (Oxford University Press, 2019) 70. See also John Ingram, 'A Food Systems Approach to Researching Food Security and Its Interactions with Global Environmental Change’ (2011) 3(4) Food Security 417.

${ }^{2}$ Friel, ibid.

3 Johan Rockström et al, 'Planet-Proofing the Global Food System' (2020) 1(1) Nature Food 3, 3; Boyd A Swinburn et al, 'The Global Syndemic of Obesity, Undernutrition, and Climate Change: The Lancet Commission Report' (2019) 393(10173) The Lancet 791.

${ }^{4}$ IPCC, Climate Change and Land: An IPCC Special Report on Climate Change, Desertification, Land Degradation, Sustainable Land Management, Food Security, and Greenhouse Gas Fluxes in Terrestrial Ecosystem (IPCC, 2019) <https://www.ipcc.ch/srccl/> 439. See also M. Crippa et al 'Food systems are responsible for a third of global anthropogenic GHG emission' (2021) 2 Nature Food 198 (finding that in 2015 'food-system emissions amounted to $18 \mathrm{Gt} \mathrm{CO}_{2}$ equivalent per year globally, representing $34 \%$ of total GHG emissions' with the 'largest contribution from agriculture and land-use/land-use change activities (71\%) and the rest 'from supply chain activities: retail, transport, consumption, fuel production, waste management, industrial processes and packaging' at 198).

${ }^{5}$ Ibid.

${ }^{6}$ IPBES, Summary for Policymakers of the Global Assessment Report on Biodiversity and Ecosystems of the Intergovernmental Science Policy Platform on Biodiversity and Ecosystem Services (2019).

7 Andrew P Dobson et al, ‘Ecology and Economics for Pandemic Prevention’ (2020) 369(6502) Science 379.
} 
Agriculture is directly responsible for the livelihoods of more than a billion people and provides employment for more than a quarter of the global population. ${ }^{8}$ Yet, at the same time land rights and livelihoods from food are also threatened by expansion of plantations and unfair labour conditions. Around two billion people experience moderate or severe food insecurity, with more than 800 million chronically undernourished, ${ }^{9}$ while diet-related chronic disease is one of the leading contributors to poor health worldwide. ${ }^{10}$ Human and ecological health, equity and sustainable livelihoods are inter-connected and inter-dependent in global food systems. ${ }^{11}$ The United Nations (UN) 2030 Agenda for Sustainable Development recognises this with Sustainable Development Goal Two (SDG 2), to 'end hunger, achieve food security and improved nutrition and promote sustainable agriculture'. The targets set for SDG 2 include ensuring sustainable food production systems and resilient agricultural practices in the context of climate change, improving land and soil quality, maintaining biodiversity, and giving smallscale food producers (including women and Indigenous peoples) secure and equal access to land. ${ }^{12}$

Action by governments, industry and other stakeholders would be all necessary to ensure access to healthy sustainable food for current and future generations in line with the Paris Agreement, SDGs and other international environmental and human rights frameworks. ${ }^{13}$ The finance sector is also an important influence on the social and ecological sustainability of global food systems. Previous empirical studies have highlighted the negative role that the financial sector has played in global food security in two ways. First, it has fuelled financial speculation that has created extreme volatility in global food commodity prices. This puts farmers out of business when prices are too low and makes food unaffordable to the poor when prices are too high. Second the financial sector also funds 'land grabs' that deprive traditional landholders,

\footnotetext{
${ }^{8}$ HLPE, Food Security and Nutrition: Building a Global Narrative Towards 2030 (High Level Panel of Experts on Food Security and Nutrition of the Committee on World Food Security, 2020) 20.

${ }^{9}$ Ibid 19.

${ }^{10}$ Ashkan Afshin et al, 'Health Effects of Dietary Risks in 195 Countries' (2019) 393(10184) The Lancet 1958

${ }^{11}$ Pamela Mason and Tim Lang, Sustainable Diets: How Ecological Nutrition Can Transform Consumption and the Food System (Taylor and Francis, 2017) 306-8.

${ }^{12}$ United Nations General Assembly, Transforming Our World: The 2030 Agenda for Sustainable Development (UN SDGs) (2015) 15-16.

${ }^{13}$ Mason and Lang (n 11) 278-300; UNEP, Collaborative Framework for Food Systems Transformation: A Multi-Stakeholder Pathway for Sustainable Food Systems. (One Planet Network Sustainable Food Systems Programme. United Nations Environment Programme, 2019)

$<$ https://www.oneplanetnetwork.org/sites/default/files/une_collaborative_framework_for_food_systems_transfo rmation_final.pdf $>$.
} 
especially smallholder farmers, of their livelihoods. ${ }^{14}$ SDG 2 , however, urges the adoption of targets for increased financial investment in agriculture in order to increase productive capacity. ${ }^{15}$ At the same time, it recognises the risk of increasing finance sector involvement in the food sector by urging the adoption of measures to limit 'extreme food price volatility', which would undermine the purpose of SDG 2. ${ }^{16}$ Such measures are necessary because otherwise increased investment in agriculture may lead to the unintended effect of increased speculation in food commodity markets, and further price volatility. Another possible way for the financial sector to ensure it is having a positive, rather than negative, impact on the food system would be for investors to adopt positive measures to address the environmental and social sustainability challenges of the food system via (voluntary or mandatory) responsible investment (RI). The potential for responsible investment in sustainable food systems has been discussed briefly in the food systems literature, but systematic empirical evidence on the extent to which investors consider sustainable food system themes in responsible investment is lacking. ${ }^{17}$

Responsible investment refers to the incorporation of environmental, social and governance (ESG) issues into investment analysis, decision-making and ownership practices. Institutional investors, financial institutions that manage funds for their beneficiaries or members, dominate global equities (share) markets and are particularly active in RI. ${ }^{18}$ Institutional investors' long

\footnotetext{
${ }^{14}$ Jennifer Clapp, 'Responsibility to the Rescue? Governing Private Financial Investment in Global Agriculture' (2017) 34(1) Agriculture and Human Values 223; Jennifer Clapp and S Ryan Isakson, Speculative Harvests: Financialization, Food, and Agriculture (Practical Action Publishing Ltd, 2018); Nicolette Larder, Sarah Ruth Sippel and Neil Argent, 'The Redefined Role of Finance in Australian Agriculture' (2018) 49(3) Australian Geographer 397.

${ }^{15}$ See SDG 2 target 2.A ('Increase investment, including through enhanced international cooperation, in rural infrastructure, agricultural research and extension services, technology development and plant and livestock gene banks in order to enhance agricultural productive capacity in developing countries, in particular least developed countries.') <https://www.un.org/sustainabledevelopment/hunger/>

${ }^{16}$ United Nations General Assembly (n 12) 16.

${ }^{17}$ But see Tomaso Ferrando, 'Financialisation of the Transnational Food Chain: From Threat to Leverage Point?' (2018) 9(3-4) Transnational Legal Theory 316; Jean-Baptiste Jouffray et al, 'Leverage Points in the Financial Sector for Seafood Sustainability' (2019) 5(10) Science Advances eaax3324; Gary Sacks and Ella Robinson, 'Investing for Health: Potential Mechanisms for the Investment Community to Contribute to Obesity Prevention and Improved Nutrition' (2018) 7(3) Current Obesity Reports 211; Phoebe Stephens and Jennifer Clapp, 'Financing Food System Regeneration? The Potential of Social Finance in the Agrifood Sector' in Jessica Duncan, Michael Carolan and Johannes SC Wiskerke (eds), Routledge Handbook of Sustainable Regenerative Food Systems (Routledge, 2020) 218; Ella Robinson et al, 'The Extent to Which Obesity and Population Nutrition Are Considered by Institutional Investors Engaged in Responsible Investment in Australia: A Review of Policies and Commitments' (2020) 11 Frontiers in Organizational Psychology (online) $<10.3389 /$ fpsyg.2020.577816>.

${ }^{18}$ Dirk Schoenmaker and Willem Schramade, Principles of Sustainable Finance (Oxford University Press, $1^{\text {st }}$ ed, 2019) 103.
} 
term investment horizons and diversified investment portfolios may predispose them towards long term value creation and the incorporation of ESG considerations into decision-making. ${ }^{19}$ As they are invested in the whole market for the benefit of a wide range of the population, it is thought that they and their beneficiaries have an interest in ensuring the longer term sustainability of the underlying businesses they invest in to ensure strong and stable returns into the future.

This paper reports a preliminary investigation of the extent to which a 'best practice' sample of Australian institutional investors, seen as leaders in RI, report using RI to address sustainable food system challenges. It aims to identify whether there is any emerging best practice RI in sustainable food among leading RI investors in Australia. This baseline audit of financial sector action (or inaction) on healthy sustainable food systems will be relevant for food policy scholars and entrepreneurs seeking to identify the potential for new governance tools to help build social and ecologically sustainable food systems. Financial actors may be able to pull levers to transform food systems that other food system actors and policy makers cannot. ${ }^{20}$ This study is also relevant to those interested in sustainable finance policy more broadly. ${ }^{21}$ Food systems may be a 'blind spot' in current industry and government governance tools aimed at encouraging more sustainable finance practices, including metrics for responsible investment, and polices aimed at encouraging social and environmental reporting and preventing 'greenwashing'. 22

The second part of this paper sets out the background to our investigation, including the relevance of sustainable food systems to RI, and the Australian context for this study. The third part describes the desktop review methodology. The fourth part presents our results. The fifth part discusses the results and draws some conclusions about possibilities for further research and action.

\footnotetext{
${ }^{19}$ James P Hawley, 'Setting the Scene: The Basics and Basis of Responsible Investment' in Tessa Hebb et al (eds), The Routledge Handbook of Responsible Investment (Routledge, 2015) 17.

${ }^{20}$ Ferrando (n 17).

${ }^{21}$ See, eg, Schoenmaker and Schramade (n 18).

${ }^{22}$ Ibid.
} 


\section{BACKGROUND}

\subsection{RI and sustainable food systems}

Commitment by institutional investors to RI is growing rapidly. The Principles of Responsible Investment (PRI), supported by the United Nations, have over 3000 signatories in 60 countries who have agreed that:

Investors' responsibility to use beneficiaries' money in line with their best interests extends beyond providing a return on their capital: it includes ensuring that money is being invested in ways that support sustainable development towards a world in which beneficiaries can live fulfilling lives...$^{23}$

The PRI aim to achieve a sustainable financial system that creates long-term value for the benefit of society and the environment alongside financial value, by incorporating ESG issues into investment analysis, decision-making and ownership practices. ${ }^{24}$ The SDGs adopted by the UN in 2015 support the adoption of RI by calling for 'an enabling economic environment', including financial systems, aimed at fulfilling the SDGs. ${ }^{25}$ The European Union is also developing voluntary and mandatory measures for financial actors to incorporate sustainability concerns into their decision-making. ${ }^{26}$

These developments are galvanising attention to the possibility for RI to play a role in the necessary transition towards 'a sustainable global financial system'.${ }^{27}$ In this ambitious vision, institutional investors should act as private governance agents (alongside government and international institutions) to positively influence businesses that they invest in towards social and environmental sustainability. ${ }^{28}$ On this view, investors can influence businesses via a repertoire of RI strategies that includes integration of ESG assessments into metrics for investment portfolio construction, engagement with investee businesses to encourage more

\footnotetext{
${ }^{23}$ UN PRI (United Nations Principles for Responsible Investment), A Blueprint for Responsible Investment (United Nations Principles for Responsible Investment, 2017) 7.

24 Ibid.

${ }^{25}$ United Nations General Assembly (n 12) cl 63.

${ }^{26}$ EU Commission, Taxonomy: Final Report of the Technical Expert Group on Sustainable Finance (Technical report, European Commission, 2020).

${ }^{27}$ UN PRI (n 23) 31.

${ }^{28}$ Michael MacLeod and Jacob Park, 'Financial Activism and Global Climate Change: The Rise of InvestorDriven Governance Networks' (2011) 11(2) Global Environmental Politics 54; Olaf Weber, 'Financial Sector Sustainability Regulations and Voluntary Codes of Conduct: Do They Help to Create a More Sustainable Financial System?' in Thomas Walker, Stéfanie D Kibsey and Rohan Crichton (eds), Designing a Sustainable Financial System: Development Goals and Socio-Ecological Responsibility (Springer International Publishing, 2018) 383.
} 
socially and environmentally sustainable action, negative screening (or disinvestment) from businesses that are too risky, and positive screening and sustainability-themed investing in new and better opportunities. A typology of RI strategies based on the one adopted by the Responsible Investment Association of Australasia (RIAA) and other RI associations around the world is shown in Table $1 .^{29}$

\section{Table 1: Typology of RI Strategies}

\begin{tabular}{|l|l|}
\hline \multicolumn{1}{|c|}{ RI Strategies } & \multicolumn{1}{c|}{ Definition } \\
\hline $\begin{array}{l}\text { 1. Negative/exclusionary } \\
\text { screening }\end{array}$ & $\begin{array}{l}\text { Systematic exclusion of specific sectors, companies or practices } \\
\text { based on ESG criteria e.g. gambling, alcohol, tobacco, weapons, } \\
\text { pornography and animal testing. }\end{array}$ \\
\hline $\begin{array}{l}\text { 2. Positive/best-in-class } \\
\text { screening }\end{array}$ & $\begin{array}{l}\text { Systematic inclusion of sectors, companies or projects based on } \\
\text { positive ESG or sustainability performance relative to industry peers. }\end{array}$ \\
\hline 3. Norms-based screening & $\begin{array}{l}\text { Screening of investments that do not meet minimum standards of } \\
\text { business practice, based on international norms and conventions (e.g. } \\
\text { those from the United Nations). May result in exclusion of assets that } \\
\text { contravene these norms and conventions or inclusion of assets that } \\
\text { uphold them. }\end{array}$ \\
\hline 4. ESG integration & $\begin{array}{l}\text { Systematic inclusion of ESG factors into traditional financial analysis } \\
\text { and investment decision-making. }\end{array}$ \\
\hline $\begin{array}{l}\text { 5. Sustainability-themed } \\
\text { investing }\end{array}$ & $\begin{array}{l}\text { Investment in themes or assets that improve social and/or } \\
\text { environmental sustainability e.g. funds that invest in clean energy, } \\
\text { green technology, sustainable agriculture and forestry, or green } \\
\text { property. }\end{array}$ \\
\hline $\begin{array}{l}\text { 7. Corporate engagement } \\
\text { and shareholder action } \\
\text { investing }\end{array}$ & $\begin{array}{l}\text { Targeted investment aimed at addressing social or environmental } \\
\text { issues, whilst also creating positive financial returns, and investment } \\
\text { in underserved individuals or communities and businesses with a } \\
\text { social and environmental purpose. }\end{array}$ \\
$\begin{array}{l}\text { Use of shareholder power to influence corporate behaviour on ESG } \\
\text { issues e.g. direct corporate engagement, such as communications with } \\
\text { senior management or boards, or filing shareholder proposals and } \\
\text { proxy voting. }\end{array}$ \\
\hline
\end{tabular}

\footnotetext{
${ }^{29}$ Adapted from R Thompson and S Bayes, Responsible Investment Benchmark Report Australia 2019 (Responsible Investment Association Australasia, 2019). See also Global Sustainable Investment Alliance (GSIA), Global Sustainable Investment Review (GSIA, 2018) <http://www.gsi-alliance.org/wpcontent/uploads/2019/03/GSIR_Review2018.3.28.pdf>; GRI, Agriculture and Fishing Sector Standard: Project Proposal (2019) <https://www.globalreporting.org/standards/standards-development/sector-standards-projectfor-agriculture-and-fishing/> .
} 
Climate disruption is of course the 'highest priority' ESG issue facing investors. ${ }^{30}$ International bodies, investors and financial regulators are urgently directing attention towards governance tools that encourage consideration of climate risks in investment decisions with a specific focus on driving a global energy transition away from fossil fuels and towards renewable energy. ${ }^{31}$ However, the food system is likely to become an increasing concern for RI, as the centrality and vulnerability of the food system to climate disruption, biodiversity loss, water scarcity, unjust working conditions, animal welfare concerns and so on becomes more obvious (as explained in the Introduction). There has been some attention to sustainable healthy food system issues by coalitions of responsible investors. For example, the 2010 Principles for Responsible Agricultural Investment that Respects Rights, Livelihoods and Resources were sponsored by the World Bank, the Food and Agriculture Organization of the United Nations (FAO), and the United Nations Conference on Trade and Development (UNCTAD). The 2014 Principles for Responsible Investment in Agriculture and Food Systems were developed through a multi stakeholder process by the Committee on World Food Security. Both initiatives sought to address land grabbing through voluntary codes but have had limited success. ${ }^{32}$ The OECD and FAO have more recently issued the OECD-FAO Guidance for Responsible Agricultural Supply Chains (2016), which applies to investors, and can be enforced via a redress mechanism under the OECD Guidelines for Multinational Enterprises (2011). CERES (a US-based non-profit network advocating for the transformation of economies to build a sustainable future) has an active programme of engagement and benchmarking on food and agriculture issues aimed at investors. Their focus includes water stewardship, climate change, and the deforestation impacts of palm oil, cattle and soy supply chains. ${ }^{33}$ Other alliances of institutional investors have taken action on specific food system issues, such as antimicrobial resistance (AMR) in animal agriculture, healthy food, and the climate and deforestation

\footnotetext{
${ }^{30}$ UN PRI (n 23). See also TCFD, Final Report: Recommendations of the Task Force on Climate-Related Financial Disclosures (Task Force on Climate-Related Financial Disclosures (TCFD), 2017) <https://www.fsbtcfd.org/wp-content/uploads/2017/06/FINAL-2017-TCFD-Report-11052018.pdf>.

${ }^{31}$ Neil Gunningham, 'Roadmaps and Regulation: Sustainable Finance in Australia' (2020) 37 Environmental and Planning Law Journal 459.

${ }^{32}$ Clapp, 'Responsibility to the Rescue?' (n 14); Ferrando (n 17).

${ }^{33}$ CERES, Feeding Ourselves Thirsty: How the Food Sector Is Managing Global Water Risks: A Benchmarking Report for Investors (CERES, 2015); CERES, Engage the Chain: Agricultural Supply Chains as a Driver of Financial Risks (2017); CERES, The Investor Guide to Deforestation and Climate Change (CERES, 2019).
} 
impacts of agriculture. ${ }^{34}$ There is some attention to sustainable food system issues in popular metrics for ESG reporting such as the Sustainability Accounting Standards Board's (SASB) reporting standards for the food and beverage, meat, and poultry and dairy sectors. ${ }^{35}$ The Global Reporting Initiative (GRI) is also working on an agriculture and fishing standard. ${ }^{36}$

One of the most comprehensive attempts to identify metrics for assessing food industry risks in relation to sustainable, healthy and fair diets is the UK Food Foundation's Plating Up Progress project. ${ }^{37}$ Plating Up Progress has identified multiple ‘urgent issues of concern' for investors in food businesses including nutritious products and services, encouraging healthy diets, climate change, biodiversity, sustainable food production, water, food waste and loss, plastics, animal welfare and antibiotics, and human rights. Each of these issues can create risks that institutional investors should take into account - physical risks (such as reductions in crop yields), regulatory risks (such as sugar taxes and the potential for regulation of livestock production), changes in consumer demand (such as growing interest in plant-based foods) and reputational risks. ${ }^{38}$ The Plating Up Progress project identifies metrics and targets that investors can use to influence companies to do two things to further the transition towards sustainable food systems: move their 'revenue dependence towards healthier and more sustainable products', and take responsibility for improving 'supply chain sustainability of the products sold'. 39

The Plating Up Progress 'urgent issues of concern' were based on scientific literature review, dietary guidelines recommendations and consultation with civil society and other

\footnotetext{
${ }^{34}$ CDP, The Forgotten 10\%: Climate Mitigation in Agricultural Supply Chains (2015); CERES and FAIRR, Global Investor Engagement on Meat Sourcing: Progress Briefing (2020); FAIRR, Coller FAIRR Protein Producer Index 2019 (Jeremy Coller Foundation, 2019); FAIRR, Responding to Resistance: Investor Exosure to Antibiotic Risk, and FAIRR's Engagement with the Restaurant Sector (2017); Feedback, Butchering the Planet: The Big-Name Financiers Bankrolling Livestock Corporations and Climate Change (2020); Matt McLuckie, Nitin Sukh and Gabriel Thoumi, Growing for Profit (Planet Tracker, 2020); ShareAction, A Healthy Investment: The Importance of Prioritising Health in the Food and Drink Manufacturing Sector (2020).

${ }^{35}$ Sustainability Accounting Standards Board (SASB), Meat, Poultry \& Dairy: Sustainability Accounting Standard (2018)

${ }^{36}$ GRI, Agriculture and Fishing Sector Standard (n 29).

${ }^{37}$ Will Nicholson, Plating Up Progress: Part 2 (Food Climate Research Network and Food Foundation (UK), 2019); Will Nicholson, Plating Up Progress: Pathways for a Healthy, Just and Sustainable Food System during a Global Pandemic (Food Foundation, 2020).

${ }^{38}$ Nicholson, Plating Up Progress: Part 2 (ibid) 4.

${ }^{39}$ Ibid.
} 
stakeholders. ${ }^{40}$ They also accord with our own understanding of the food systems literature. ${ }^{41}$ We therefore adapted the Plating Up Progress schema of food sustainability themes for our desktop review. We do not address the nutrition and health themes covered by Plating Up Progress in this paper as we addressed those issues in a separate paper using a separate and more detailed coding schema. ${ }^{42}$ Plating Up Progress focused on investment risks and opportunities specifically in food retailing, such as restaurants, supermarkets and catering providers. However, the same themes are also relevant to agribusinesses, agricultural assets and food production and processing companies. Our version of the criteria therefore addresses both the agricultural production and retailing aspects of the food system. Table 2 shows our version of these criteria. ${ }^{43}$

\footnotetext{
${ }^{40}$ Harriet Bartlett and Tara Garnett, Metrics for Sustainable Healthy Diets: Why, What, How? (Food Climate Research Network and The Food Foundation, 2016).

${ }^{41}$ See for example the previous work of the various authors in Rachel Carey et al, 'Opportunities and Challenges in Developing a Whole-of-Government National Food and Nutrition Policy: Lessons from Australia's National Food Plan' [2016] Public Health Nutrition 1; Christine Parker and Hope Johnson, 'Sustainable Healthy Food Choices: The Promise of "Holistic" Dietary Guidelines as a National and International Policy Springboard' (2017); Swinburn et al (n 3).

${ }^{42}$ See Robinson et al (n 17)

${ }^{43}$ Adapted from Nicholson, Plating Up Progress: Part 2 (n 37); Nicholson, Plating Up Progress: Pathways (n 37).
} 
Table 2: Definitions and Coding Strategies for Sustainable Food System Themes

\begin{tabular}{|l|l|}
\hline Key Themes & Definitions \\
\hline Climate Change & Greenhouse gas emissions from the food system including land use change. \\
\hline Biodiversity & $\begin{array}{l}\text { Biodiversity loss attributable to deforestation and land use change for } \\
\text { agriculture (overlaps with climate change), over-fishing, pesticide use and } \\
\text { management of genetically modified organisms. }\end{array}$ \\
\hline Water & $\begin{array}{l}\text { Use of water in agricultural production and food processing; and risk of } \\
\text { water scarcity (overlaps with climate change). }\end{array}$ \\
\hline $\begin{array}{l}\text { Food loss and } \\
\text { waste }\end{array}$ & $\begin{array}{l}\text { Adoption of initiatives to reduce food loss and waste throughout the food } \\
\text { supply chain. }\end{array}$ \\
\hline Human rights & $\begin{array}{l}\text { Human rights relating to labour rights (modern slavery obligations, } \\
\text { underpayment and other fair labour practices), land rights and Indigenous } \\
\text { rights. }\end{array}$ \\
\hline $\begin{array}{l}\text { Animal welfare } \\
\text { and antimicrobial } \\
\text { resistance (AMR) }\end{array}$ & $\begin{array}{l}\text { Animal welfare and animal cruelty in animal agriculture and aquaculture for } \\
\text { food. } \\
\text { Over-use of antibiotics in animal agriculture and aquaculture creating risk of } \\
\text { AMR with harm to human or animal health. }\end{array}$ \\
\hline $\begin{array}{l}\text { Sustainable food } \\
\text { production } \\
\text { practices }\end{array}$ & $\begin{array}{l}\text { Adoption of approaches to promote environmentally (and socially) } \\
\text { sustainable agriculture } \\
\text { Also includes issues related to sustainable food production not captured by } \\
\text { the categories above. }\end{array}$ \\
\hline
\end{tabular}

\subsection{RI and food systems in Australia}

Australia is a country rich in agricultural resources and with a large and active institutional investor sector. We therefore expect Australia to be a good test of whether and how institutional investors consider sustainable food system themes in RI.

Australia has the fourth-largest pool of investment fund assets in the world, mainly because of compulsory superannuation contributions by employers. ${ }^{44}$ The RIAA reported that responsible investors managed 44\% of professionally managed assets in Australia in 2018, up 13\% from the previous year. ${ }^{45}$ The (not for profit) industry superannuation funds are thought to be

\footnotetext{
${ }^{44}$ Australian Sustainable Finance Initiative (ASFI), Australian Sustainable Finance Roadmap (2020) $<$ https://www.sustainablefinance.org.au/>; Anna Young-Ferris and Louise O'Halloran, 'Responsible Investment in Australia' in Tessa Hebb et al (eds), The Routledge Handbook of Responsible Investment (Routledge, 2015) 149.

45 Thompson and Bayes (n 29).
} 
particularly receptive to integration of ESG factors ${ }^{46}$ and have spearheaded the growth of RI in Australia. ${ }^{47}$ Mees and Smith have argued that "Australia has some of the most "activist" institutional investors' in the world since 'over $10 \%$ of listed capital [is] held by superannuation plans co-sponsored by unions'. ${ }^{48}$ This means that Australia has become 'one of the more notable jurisdictions for institutional influence in corporate governance reform' including in relation to 'executive remuneration, environmental sustainability and gender diversity on corporate boards' ${ }^{49}$

The Australian Securities Exchange (ASX) supports the integration of ESG factors into investment practice by encouraging listed companies to 'disclose whether it has any material exposure to environmental or social risks, and, if it does, how it manages or intends to manage those risks'. 50 'Environmental risks' are defined to include 'the risks associated with the entity polluting or degrading the environment, adding to the carbon levels in the atmosphere, or threatening a region's biodiversity or cultural heritage. It also includes the risks for the entity associated with climate change, reduced air quality and water scarcity. ${ }^{51}$ 'Social risks' are defined to include 'the risks associated with the entity or its suppliers engaging in modern slavery, aiding human conflict, facilitating crime or corruption, mistreating employees, customers or suppliers, or harming the local community. ${ }^{52}$ Financial institutions who offer investment products to retail clients, such as superannuation, managed investment products and life insurance products are also legally required to disclose 'the extent to which labour standards or environmental, social or ethical considerations are taken into account in the

\footnotetext{
${ }^{46}$ Bernard Mees and Sherene A Smith, 'Corporate Governance Reform in Australia: A New Institutional Approach' (2019) 30(1) British Journal of Management 75; Claire Parfitt, 'Contradictions of Financialised Neoliberalism: The Contemporary Practice of Responsible Investment’ (2018) 54(1) Journal of Sociology 64.

${ }^{47}$ Emmy Labovitch and Nikolaj Halkjaer, Private Retirement Systems and Sustainability: Australia (United Nations Principles for Responsible Investment (UN PRI), 2020) 16.

${ }^{48}$ Mees and Smith (n 46) 76.

${ }^{49}$ Ibid. See also Association of Superannuation Funds of Australia (ASFA), Superannuation Fund Governance: Understanding the Framework, Addressing the Issues, Best Practice Paper No. 7 (2020) ; Financial Services Council (FSC), FSC Standard No. 20 Superannuation Governance Policy (2013) section 10; Australian Council of Superannuation Investors (ACSI), ACSI Governance Guidelines (2019) section 5; Australian Institute of Superannuation Trustees (AIST), AIST Governance Code Guidance (2018).

${ }^{50}$ ASX Corporate Governance Council, Corporate Governance Principles and Recommendations: 4th Edition, February 2019 (ASX, 2019) <https://www.asx.com.au/documents/regulation/cgc-principles-andrecommendations-fourth-edn.pdf $>$ Recommendation 7.4. Note the 'if not, why not' approach is adopted to compliance with the Corporate Governance Principles and Recommendations. That is, listed companies must either comply or explain why they do not comply.

${ }^{51}$ Ibid, Glossary, p 35.

${ }^{52}$ Ibid, Glossary, p36.
} 
selection, retention or realisation of the investment' (Section 1013D(1)(1) Corporations Act Cwth 2001). ${ }^{53}$ This requirement covers most institutional investors. Australian financial regulators, the Australian Securities and Investments Commission (ASIC) and the Australian Prudential Regulatory Authority (APRA) are currently taking steps to require companies, banks and other financial institutions to disclose their approach to managing climate risks in line with global standards. ${ }^{54} \mathrm{~A}$ collaboration of institutional investors, finance sector peak bodies and academics has also created a Sustainable Finance Roadmap for Australia recommending further actions to align Australia's financial system 'with a sustainable, resilient and prosperous future' in line with the SDGs, Paris Agreement, Sendai Framework for Disaster Risk Reduction and Convention on Biological Diversity (CBD). ${ }^{55}$

Agriculture has generally been considered a risky investment in Australia, best avoided by institutional investors, because of the nation's highly variable climatic conditions. ${ }^{56}$ Moreover, many agricultural enterprises in Australia are privately held by smaller family businesses or large private concerns and therefore do not offer shares to the public. However, investor interest in agriculture is growing, and the Australian Government is encouraging greater private investment in agriculture to increase its competitiveness and efficiency. ${ }^{57}$ The agriculture industry is consolidating and looking for new forms of finance. Even if they are not invested in agriculture, most institutional investors are invested in food businesses, and food businesses depend on and influence agricultural businesses. The ASX top 20, in which most institutional investors hold shares, includes the two major Australian supermarkets - Wesfarmers (Coles) and Woolworths. These supermarkets are arguably the most powerful agents in relation to food

\footnotetext{
${ }^{53}$ They must do so in their 'Product Disclosure Statements' which must be given to all retail clients. For more details see, ASIC, Regulatory Guide 65: Section 1013DA Disclosure Guidelines (ASIC, 2011) <https://download.asic.gov.au/media/1239069/rg65-published-30-november-2011.pdf>.

${ }^{54}$ See Cathie Armour, Managing Climate Risk for Directors (ASIC, 2021) https://asic.gov.au/about-asic/newscentre/articles/managing-climate-risk-for-directors/; Geoff Summerhayes, Understanding and Managing the Financial Risks of Climate Change (Letter to all APRA-regulated entities) <https://www.apra.gov.au/understanding-and-managing-financial-risks-of-climate-change> (APRA, 2020); 'APRA's response to climate-related financial risks' (APRA, undated) at <https://www.apra.gov.au/apra'sresponse-to-climate-related-financial-risks $>$. For further explanation and discussion of these developments, see Darren Sinclair, 'Speak Loudly and Carry a Small Stick: Prudential Regulation and the Climate, Energy, and Finance Nexus’ (2019) 59(2) Jurimetrics 141.

55 ASFI (n 44); Gunningham (n 31).

${ }^{56}$ Parliament of Australia, Super-Charging Australian Agriculture: Inquiry into Superannuation Fund Investment in Agriculture (House of Representatives Standing Committee on Agriculture and Water Resources, Parliament of the Commonwealth of Australia, 2018).

${ }^{57}$ Ibid; Larder, Sippel and Argent (n 14).
} 
and agriculture businesses in Australia. ${ }^{58} \mathrm{~A}$ variety of other food companies and primary producers with processing or export arms also feature on the ASX, such as Inghams (chicken meat), Tassal (salmon farming), and Costas (fruit and vegetable production). Australian institutional investors also invest in a range of food processing and retail businesses listed in overseas jurisdictions. Food and agriculture are inextricably linked. Australian and international food processing and retail businesses have significant supply chain influence over agricultural producers and can also influence consumer diets, making them potentially a strategic focus for governance efforts to ensure a sustainable healthy food system. ${ }^{59}$

There has been little published scholarly or industry attention to food system sustainability issues in RI in Australia. ${ }^{60}$ Yet, consumer research suggests that members of Australian superannuation and investment funds want to see their money invested in sustainable land and agricultural management. ${ }^{61}$ Moreover, there are reports that many investors expect RI funds to screen out risky agricultural practices, such as pesticide use and practices that lead to animal cruelty. ${ }^{62}$ There has been no previous systematic empirical study of the use of RI strategies by institutional investors in relation to sustainable food issues in Australia. In a previous study, we examined the extent to which obesity prevention and population nutrition are considered by Australian institutional investors engaged in RI, using the same sample and similar methodology as the current study. ${ }^{63}$ In the previous study, eighteen of the 35 investors reviewed indicated that they applied RI strategies that considered obesity and population nutrition themes, albeit mostly in a limited way. The current study reports on additional complementary data (which has not previously been reported) examining how institutional investors incorporate sustainable food system themes into RI.

\footnotetext{
58 Jane Dixon, 'Supermarkets as New Food Authorities' in D. Burch and G. Lawrence (eds) Supermarkets and Agri-Food Supply Chains (Edward Elgar, 2007) 29; Christine Parker and Gyorgy Scrinis, 'Out of the Cage and into the Barn: Supermarket Power Food System Governance and the Regulation of Free Range Eggs' (2014) 23(2) Griffith Law Review 318; Kiah Smith, Geoffrey Lawrence and Carol Richards, 'Supermarkets' Governance of the Agri-food Supply Chain: Is the “Corporate-Environmental” Food Regime Evident in Australia?' (2010) 17(2) International Journal of Sociology of Agriculture and Food 140.

${ }^{59}$ Dixon (ibid); Harriet Friedmann, 'From Colonialism to Green Capitalism: Social Movements and the Emergence of Food Regimes' in Frederick Buttel and Philip McMichael (eds), New Directions in the Sociology of Global Development (Elsevier, 2005) 227.

${ }^{60}$ But see ClimateWorks Australia, Land Use Futures: Natural Capital Roadmap (ClimateWorks Australia, 2019).

${ }^{61}$ RIAA, From Values to Riches 2020: Charting Consumer Expectations and Demand for Responsible Investing in Australia (Responsible Investment Association Australasia, 2020) 11.

${ }^{62}$ Ibid.

${ }^{63}$ Robinson et al (n 17).
} 


\section{METHODS}

This study involved a desk-based review of RI in relation to sustainable food system themes. A best practice sample of 35 asset managers and superannuation funds was identified through publicly available benchmarking reports. Data were collected through a web-based search of RI approaches for each investor in the sample, using key terms related to food system sustainability. A desk-based approach was chosen to manage the scope of this exploratory study. Further details on each step are outlined below. ${ }^{64}$

\subsection{Sample}

The most prominent asset managers and superannuation funds engaged in RI in Australia were identified through publicly available reports created by the RIAA. The RIAA is the leading industry association for RI in Australia and New Zealand. It releases yearly reports that monitor and benchmark the size and ESG performance of Australian institutional investors. ${ }^{65}$

The group of 35 institutional investors included in this study (shown in the Appendix, Table A1) is made up of three groups:

1) Twenty-one Australian asset managers identified by RIAA as 'applying a leading approach to ESG integration' in $2019 .^{66}$

2) Three additional asset managers identified by RIAA in 2018 as among the largest asset managers (by amount under management) using RI strategies other than ESG integration. ${ }^{67}$

3) Eleven superannuation funds classified as 'leading' funds by the RIAA in $2019 .{ }^{68}$

\footnotetext{
${ }^{64}$ See also ibid.

65 Thompson and Bayes (n 29) 22.

${ }^{66}$ Ibid 9-10, 21-2. 'Leading approach' was defined by the RIAA as having scored over $80 \%$ on the RIAA ESG integration assessment, which was based on a desktop review of each investment manager. Only $28 \%$ of those investment managers assessed by RIAA were included in this leading group. Two funds were excluded for the purpose of this study: JCP Partners which was no longer in business, and New Forests which invested exclusively in forestry.

${ }^{67}$ Responsible Investment Association Australasia (RIAA), Responsible Investment Benchmark Report 2018 (2018) <https://responsibleinvestment.org/wpcontent/uploads/2018/08/RIAA_RI_Renchmark_Report_AUS_2018v6.pdf>14. There was no useable list of largest funds in the 2019 benchmark report, so this group could not be updated for 2019 .
}

${ }^{68}$ N Boele et al, Responsible Investment Super Study 2019 (RIAA, 2019). Leading superannuation funds were defined by RIAA as the top $25 \%$ of all superannuation funds assessed with reference to RIAA's 'Framework of Good Responsible Investment Governance' and a scale 'indicating the quality and scope of disclosures'.

Australian superannuation funds had not been included in the first and second groups because they were not included in the RIAA benchmark report. However, one asset manager, Australian Ethical, included in the first group is also a superannuation fund. Two sovereign wealth funds were excluded as they operate according to a different set of principles: Future Fund and NZ Super Fund. 
Asset managers and superannuation funds were only included if they were headquartered in Australia or identified as Australian investors by RIAA.

This was not intended to be a representative sample of institutional investors but rather a best practice sample. It is therefore not appropriate to draw inferences from this sample about the extent to which institutional investors more generally take food system sustainability issues into account. This study of 35 asset managers and superannuation funds does, however, provide good insight into the extent to which there is any emerging best practice in Australia in relation to RI for sustainable food systems, as we expect this sample to be at the leading edge of RI practice.

\subsection{Data}

First, a general search of the websites of each investor was conducted (as at December 2019) to identify pages and documents related to each investor's RI strategies, policies, or approaches. Relevant webpages were then searched using key terms relating to sustainable food system themes including: agriculture, protein, palm oil, organic, pesticide, glyphosate, regenerative [agriculture], animal, fishing, farming, animal welfare, slavery, deforestation, land clearing/use, food [system/supply]. Additionally, a search of publicly available data in the 2019 UNPRI transparency reports of each investor was conducted, using the same key terms. All the institutional investors included in this review had a publicly available 2019 PRI report (except Future Super which became a signatory in June 2019). Relevant documents, articles and webpages were downloaded, or images captured.

This approach is consistent with other initiatives that assess corporate practice and performance in regard to food system issues on the basis of publicly available information. ${ }^{69}$ However, since we relied only on publicly available material, we may have missed some policies or practices relating to RI and sustainable food systems that have not been made public. and we are also not able to test public statements against any more detailed internal procedures. Nor were we able to evaluate investor strategies against the businesses and assets that they actually invested in. Further research including in-depth interviews with asset managers and other stakeholders will enable better understanding of current practice. Future analyses should also critically

\footnotetext{
${ }^{69}$ See, eg, Nicky Amos, Rory Sullivan and Heleen van de Weerd, The Business Benchmark on Farm Animal Welfare (BBFAW) Methodology Report (BBFAW, 2019); FAIRR, Coller FAIRR Protein Producer Index 2019 (Jeremy Coller Foundation, 2019); Nicholson, Plating Up Progress: Pathways (n 37).
} 
examine the relationship between investors' disclosed investment strategies and their actual investment portfolios, if access to that data can be made available.

\subsection{Content Analysis}

A content analysis of the data collected was conducted to identify whether and how each institutional investor considered each of the seven sustainable food system themes shown in Table 2 (above). RI strategies mentioned in relation to each theme were coded using word processing software according to the seven-fold typology shown in Table 1 (above). Additional coding criteria are shown in Appendix Tables A2 and A3. All codes were initially assigned by one coder (LB) and then were cross-checked by a second coder (ER). Any discrepancies in agreement between the two coders were then discussed and resolved by the authorship team.

\section{RESULTS}

\subsection{Overview of results}

Twenty-one of the thirty-five institutional investors explicitly stated that they used at least one RI strategy in relation to at least one food system theme. Of the 35 institutional investors reviewed, only one, AE (a small fund with less than \$3billion AUM), had an explicit and holistic policy on sustainable food systems. AE reported that it invests only in businesses that align with the principles in their Ethical Charter. This Charter has clear principles relating to food and agriculture (food must form part of a healthy diet; be produced in an environmentally sustainable way; and avoid unnecessary harm to humans and animals). Boutique fund Stewart also showed understanding of food system issues in 6 of the 8 themes. Sixteen of the 35 investors did not specifically mention ESG issues raised by food systems anywhere in their public documents. The results are summarised in Table $3 .^{70}$

The most common themes were 'human rights', specifically labour rights in the food supply chain, 'animal welfare and AMR' (10 investors each $\left.{ }^{71}\right)$; followed by 'sustainable agriculture' (8 investors). 'Climate change', 'biodiversity loss', and 'water use' were each addressed by 6 investors. Only 2 investors addressed 'food loss and waste'. Each theme is discussed in turn below.

\footnotetext{
${ }^{70}$ In-depth details of the coded text and sources is available from the first author upon request.

${ }^{71}$ Each investor has been counted only once in relation to each theme, even if they used more than one strategy or had more than one instance or policy relating to each theme.
} 
The most common responsible investment strategy in relation to food systems was 'corporate engagement and shareholder action' (13 investors), mainly driven by concerns with labour rights in fresh food supply chains and intensive animal agriculture. The next most common strategies used were 'negative or exclusionary screening', 'ESG integration', and 'sustainability-themed investment' (7 investors each). A small number of investors reported using 'positive or best-in-class screening' or 'impact or community investing' (2 investors each). No investors stated that they used 'norms-based screening' for food system sustainability issues. We report on which RI strategies were used in relation to each theme below. 
Table 3: Australian Institutional Investors' Reported Use of RI Strategies to address Food System Sustainability Themes 2019 (n=35)

\begin{tabular}{|c|c|c|c|c|c|c|c|}
\hline RI Strategy & $\begin{array}{c}\text { Climate } \\
\text { (6) }\end{array}$ & $\begin{array}{c}\text { Biodiversity } \\
\text { (6) }\end{array}$ & $\begin{array}{l}\text { Water } \\
\text { (5) }\end{array}$ & $\begin{array}{l}\text { Sustainable } \\
\text { Food } \\
\text { Production } \\
\text { (8) }\end{array}$ & $\begin{array}{c}\text { Food Loss \& } \\
\text { Waste } \\
\text { (2) }\end{array}$ & $\begin{array}{c}\text { Animal welfare \& } \\
\text { AMR } \\
\text { (10) }\end{array}$ & $\begin{array}{c}\text { Human Rights } \\
\text { (10) }\end{array}$ \\
\hline $\begin{array}{l}\text { Negative/ } \\
\text { Exclusionary screening (7) }\end{array}$ & $\begin{array}{l}\mathrm{AE}^{1} \\
\text { Stewart }\end{array}$ & $\begin{array}{l}\mathrm{AE} \\
\text { Christian } \\
\text { Perpetual }\end{array}$ & $\mathrm{AE}$ & & & $\begin{array}{l}\mathrm{AE} \\
\text { Care }^{2} \\
\text { Christian } \\
\text { Future } \\
\text { Pengana }^{2} \\
\end{array}$ & $\mathrm{AE}$ \\
\hline $\begin{array}{l}\text { Positive/ } \\
\text { Best-in-class screening (3) }\end{array}$ & $\mathrm{AE}$ & & & $\begin{array}{l}\text { LG } \\
\text { Stafford }\end{array}$ & & & \\
\hline \multicolumn{8}{|l|}{ Norms based screening (0) } \\
\hline ESG integration (7) & $\begin{array}{l}\text { Stafford } \\
\text { Stewart }\end{array}$ & $\begin{array}{l}\text { Future } \\
\text { Stafford } \\
\text { Stewart }\end{array}$ & $\begin{array}{l}\text { Stafford } \\
\text { Stewart } \\
\text { Wavestone } \\
\end{array}$ & LG & Stewart & Stewart & $\begin{array}{l}\text { AMP } \\
\text { Colonial }\end{array}$ \\
\hline $\begin{array}{l}\text { Sustainability- themed } \\
\text { investing ( } 7)\end{array}$ & $\begin{array}{l}\text { AMP } \\
\text { CBUS } \\
\text { Stafford } \\
\text { Stewart }\end{array}$ & Stewart & Stewart & $\begin{array}{l}\text { AMP } \\
\text { AE } \\
\text { HESTA } \\
\text { Stafford } \\
\text { U Ethical }\end{array}$ & & - & \\
\hline $\begin{array}{l}\text { Impact/Community } \\
\text { investing (2) }\end{array}$ & & & Vic Super & $\begin{array}{l}\text { Christian } \\
\text { Vic Super }\end{array}$ & Christian & - & Christian \\
\hline $\begin{array}{l}\text { Corporate engagement and } \\
\text { shareholder action (13) }\end{array}$ & UniSuper & $\begin{array}{l}\text { AE } \\
\text { Future } \\
\text { Stewart }\end{array}$ & Wavestone & $\mathrm{AE}$ & & $\begin{array}{l}\text { AMP } \\
\text { Ausbil } \\
\text { AE } \\
\text { Future } \\
\text { HESTA }\end{array}$ & $\begin{array}{l}\text { AMP } \\
\text { Ausbil } \\
\text { AE } \\
\text { IFM } \\
\text { Pendal } \\
\end{array}$ \\
\hline
\end{tabular}

${ }^{1}$ Names of businesses have been abbreviated. All abbreviations are shown in Table A1 in the Appendix.

${ }^{2}$ There is a 5-10\% threshold at which companies can generate revenue from animal use (eg how much meat they sell) before they are negatively screened. 


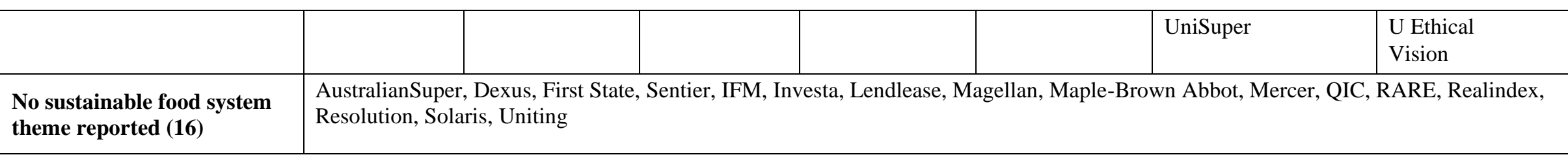




\subsection{Climate change}

Only Australian Ethical (AE), a small ethically focused retail fund, had a specific policy in relation to investing in the food system, which included a 'negative' and 'positive screen' requiring food producers to be 'aligned with limiting global warming to below $2^{\circ} \mathrm{C}$ '. Two investors, AE and Stewart Investors (Stewart), negatively screened livestock agriculture because of climate and other impacts. As a boutique fund focused on sustainability-themed international investments, Stewart declared that they did not invest in livestock due to the climate impact of deforestation for grazing and feed production in places like the Amazon.

Stewart and Stafford referred to climate change ESG integration specifically in relation to food and agriculture. Stafford, a boutique fund which takes a long term 'stewardship' approach, commented on the potential impact of climate change on their long-term investments in agricultural land. These potential impacts included possible regulatory changes such as the introduction of carbon pricing, the risk of reduction in groundwater entitlements and the ability to access water for irrigation, the possible need to change the highest and best use of land as climate regions shift, and potential cost increases from the need 'to shift towards zero emission farming'.

Four investors saw climate change as an opportunity for 'sustainability-themed investing' in food and agriculture. For example, Stafford saw their heavy focus on agricultural land as positioning themselves 'for the transition to a lower carbon economy' since 'sustainable agriculture' would be one of the 'vital assets to help support and enable the transition that is required'. AMP highlighted their investments in 'Adaptation projects including those providing ... food security and stress resilient agricultural systems'. CBUS reported that it had 'approved a dedicated allocation to climate investment opportunities of approximately $\$ 500 \mathrm{~m}$ ... to support climate transition' and that it expected to include agriculture in this new allocation. Stewart highlighted their investments in companies producing more sustainable food.

One investor, UniSuper, mentioned 'climate resilience and adaption' as an 'ongoing and emerging' aspect of engagement specifically in relation to 'sustainable food systems', which in context may have been a reference to livestock farming. 


\subsection{Biodiversity loss}

Three investors stated they used 'negative screening' in relation to biodiversity loss. AE's comprehensive ethical criteria negatively screens food businesses that engage in 'ecological land clearing', particularly for 'palm oil production'. Palm oil plantations are a distinct driver of deforestation for South East Asia. ${ }^{79}$ Demand for palm oil and therefore deforestation for palm oil plantations is growing as palm oil is used in a wide range of products, including about half of all supermarket products. ${ }^{80}$ AE reported that they did however invest in businesses that use palm oil in products (which can often include food businesses), but 'positively screen' by requiring that 'any palm oil used [in products] is certified sustainable'. AE also stated that they negatively screened fishing for wild fish and fish-farming because of the impact on ocean 'biodiversity'. AE divested from Tassal (a Tasmanian salmon farming business) in 2017 due to its use of wild fish (anchovies) as fish feed and other environmental concerns. ${ }^{81}$ Christian Super, a small fund based in Christian community schools, stated that they negatively screened 'companies and technologies that negatively affect the ocean, whether through pollution, promoting climate change, or over-fishing'. AE and Perpetual also both reported that they negatively screened food businesses that sell genetically modified seeds and associated pesticides on the basis that these too contribute to biodiversity loss.

Three investors reported using 'ESG integration strategies' in relation to biodiversity loss. Stewart and Stafford both stated that they were concerned about deforestation due to biodiversity and climate change impacts. Stewart detailed their decision making about whether to stay invested in a particular palm oil producer due to concerns about deforestation and biodiversity loss. Stafford also note the complexity of seeking to completely exclude investment in deforestation since 'a company that is making a large positive impact on reducing hunger [in line with Sustainable Development Goal 2] may at the same time be having a small negative impact on deforestation as it increases the acreage it uses to produce food.'

Stewart highlighted the impact of pesticides on biodiversity, reporting that they have sustainability-themed investments 'in companies providing [bio technological] solutions like

\footnotetext{
${ }^{79}$ See WWF International, Deforestation Fronts: Drivers and Responses in a Changing World (WWF, 2021) < https://www.worldwildlife.org/stories/deforestation-fronts>

${ }^{80}$ Friends of the Earth Australia, Draw the Line: A Black Book About the Shady Investments of Australian Banks in Palm Oil (Friends of the Earth Australia, 2019) 11.

${ }^{81}$ For more on this topic more recently, see Richard Flanagan, Toxic: The Rotting Underbelly of the Tasmanian Salmon Industry (Penguin, 2021).
} 
Novozymes who are producing microbes that help increase soft commodity yields and reduce the need for chemical herbicides and pesticides'.

Three other investors saw biodiversity loss as an issue for 'engagement'. For example, in relation to pesticides, AE stated that although they 'do not currently invest in chemical or pesticide companies', they 'do not have a blanket exclusion'. Instead, their policy is corporate engagement and shareholder action:

Excessive and inappropriate use of chemicals and pesticides is a major concern, but both naturally and non-naturally occurring chemicals can have beneficial uses. We will look at companies and chemicals on a case by case basis. We work to exercise a positive investor influence by supporting the Chemical Footprint Project, which is encouraging companies to better manage and disclose how they deal with chemicals in their products, manufacturing operations, and supply chains.

Future Super reported on engagement on biodiversity loss in relation to an investee business producing omega oil supplements and whether they were based on over-fishing, which would have excluded investment. As a result of engagement, Future Super were happy that the business had an ethical supply chain for the fish it used in its products.

\subsection{Water use}

One investor, AE, stated that they used 'negative screening' in relation to 'wasteful water use' by food producers. Three investors discussed 'ESG integration' in relation to water use in agricultural land. For Stafford and Stewart, this was linked to water scarcity due to a changing climate and efficient water use by food businesses. Wavestone also commented on both 'ESG integration' and corporate 'engagement' in relation to water management in agriculture:

...Currently only $0.5 \%$ of the planet's water is available for use by mankind [sic] and global ecosystems and massive investment will be needed to upgrade and expand current water infrastructure to meet future demand and protect water quality. Equally industries heavily reliant on water could face significant risks due to conflict over water supply and consequently costs of water usage will rise. We assess and engage with companies on how they manage their water usage, interact with the local community and manage supply risks. 
Vic Super ${ }^{82}$ highlighted their impact investment in the Murray Darling river basin, Australia's major river basin which is crucial to water for irrigation and the environment, including in important food-producing regions. ${ }^{83}$

\subsection{Sustainable food production}

In relation to 'positive screens', LG Super stated that they 'seek out investment opportunities that have a positive social and/or environmental impact on society' including through 'sustainable agriculture'. Stafford reported using 'best-in-class screening', stating that they were:

focused on making the global agriculture and food sector more investible and improving agricultural productivity in a sustainable way by combining capital with best-in class industry operators.

LG Super also reported that one of the common 'ESG integration' issues it considered is 'food security and sustainable agriculture'.

Five investors referred to 'sustainability themed investment' in 'sustainable agriculture' - but mostly with little detail about what this might mean. For example, U Ethical included 'sustainable agriculture' on a list of areas where they 'proactively invest'. However, Stewart talked about their investments in soy product manufacturers Kikkoman and Vitasoy as sustainable investments on a range of dimensions including as traditional alternatives to beef, pork and dairy in line with the SDGs, because 'soy-based protein has fewer environmental challenges and requires less water to produce'. Moreover, they stated that they considered other social and environmental justice issues that might arise from the supply chain for soy beans arguing that Vitasoy's 'values clearly extend into their supply chain approach. There is a policy of not sourcing soy beans from South America due to the risk of deforestation linked to soy production. Instead, soy beans are mainly procured from Canada and China, where they require suppliers to certify no deforestation impacts'.

Christian Super reported some 'impact investments' related to 'sustainable agriculture' including work with 'the world's poorest farmers' in organic coconut farming (mentioned below in relation to human rights). Similarly, Vic Super, highlighted their impact investment

\footnotetext{
${ }^{82}$ A public super fund originally created as a government run fund for public service employees in the state of Victoria,

${ }^{83}$ Their impact investment is a long term "landscape redevelopment project" called "Future Farming Landscapes" (FFL).
} 
in the crucial Murray Darling river basin through the Future Farming Landscapes redevelopment project (already mentioned above).

\subsection{Food loss and waste}

Only two investors mentioned 'food loss and waste'. Stewart highlighted one example of 'ESG integration' as investment in Kikkoman, a soy product company that uses, 'closed loop production processes [for] waste capture and use for animal feed and fuel for boilers'. Christian Super, reported an 'impact investment' in a start-up that provides a technological solution for 'dramatically' reducing food waste in commercial kitchens.

\subsection{Human rights}

Only AE specifically mentioned 'negative screening' in relation to human rights in the food system. AE pointed out that 'food production is susceptible to human rights breaches because it is labour intensive and workforces are often seasonal and isolated'. They stated that 'food processors must be taking steps to manage the human rights risks in their supply chains, and they should have an ethical sourcing policy as an absolute minimum' in order to be investable.

Two investors discussed 'ESG integration' issues in relation to human rights and food. AMP reported that after 'monitoring the underpayment of wages at an Australian fast food company for quite some time', they divested from that company. Colonial reported that they had downgraded major Australian supermarket Woolworths' ESG assessment from low to moderate risk, noting that:

While Woolworths has commendably exceeded its target to reduce carbon emissions and has partnered with Replast to address plastic waste, we hold concerns over the risks associated with allegations of underpaying employees found by the Fair Work Ombudsman. We anticipate that ongoing legal action from the Retail and Fast Food Workers Union, who are seeking damages of over AUD 1 billion in back pay, could trigger a structural change. Ethical sourcing of products such as palm oil and seafood also remains a concern, but due to investor pressure and the Modern Slavery Act [which requires Australian companies to publicly report on unfair labour practices in their supply chains], policies are being adopted by Woolworths to improve the social supply chain standard.

Seven investors specifically mentioned corporate 'engagement' in relation to human rights and labour concerns in fresh food supply chains. Much of the engagement related specifically to the implementation of the Modern Slavery Act 2018 (Cth) in Australia (and earlier in the UK) which requires larger businesses to assess and report on the possibility there is modern slavery 
in their supply chains. ${ }^{84}$ For example, AMP referred to Oxfam's scoring of 'US and European supermarkets' on modern slavery in their food supply chains and reported that they 'continue to engage with these companies'. IFM Investors reported that it had 'initiated an engagement process' with Woolworths 'demanding improved human rights management in the fresh food supply chain, particularly relating to labour hire practices'.

Ausbil commented on food as a high-risk area for human rights in supply chains:

In terms of industries, key hot spots / high risk areas include: Agricultural and fishing industries, e.g. coffee from Latin America and Africa, fish from Thailand, Cambodia, Indonesia and various African countries, palm oil from Sierra Leone and south-east Asia, rice from Brazil, India, Kenya, tea from east Africa, tobacco from various countries in South America and Africa.

No investor mentioned 'sustainability-themed investment' in relation to human rights issues, but Christian Super reported an 'impact investment' in a fund that works directly with 'organic coconut farmers, paying certified fair-trade wages, supporting sustainable agriculture and operating social programs to improve livelihoods'.

\subsection{Animal welfare and AMR}

Five investors stated that they negatively screen intensive animal agriculture to some degree due to concerns about animal welfare. AE negatively excluded investment in any form of animal agriculture as it breaches all three of their ethical criteria for food production - health, environmental sustainability and harm to humans and animals:

Current commercial meat production causes great suffering to animals. The majority of animal products consumed today are produced in intensive systems with high density stocking and accelerated fattening... We assess the harm to animals and the environment (including climate) caused by current large-scale commercial animal agriculture as unnecessary because balanced plant-based diets can sustain healthy human life ... As a result, we exclude investment in current systems of commercial animal agriculture including meat, dairy, eggs and seafood ...

AE also address supply chain issues by ensuring that any food businesses they do invest in keep their use of animal-derived ingredients below a certain threshold.

Stewart mentioned animal welfare as an ESG integration issue in relation to potential investment or divestment and identified AMR as a concern with ESG integration in relation to

\footnotetext{
${ }^{84}$ Jolyon Ford and Justine Nolan, 'Regulating Transparency on Human Rights and Modern Slavery in Corporate Supply Chains' (2020) 26(1) Australian Journal of Human Rights 27.
} 
animal agriculture. AE also cite concerns about AMR as a reason to negatively screen animal agriculture.

Four investors reported corporate engagement on animal welfare. Three of these stated that they engaged on animal welfare issues with live export of sheep or cattle from Australia to Asia and the Middle east, which has been a particularly contentious issue for the Australian public. For example, Ausbil stated that it,

continued its discussions with Australian Agricultural Company in relation to live export... Ausbil discussed the company's animal welfare standards and the accreditation program in use. Animal welfare, particularly in relation to live exports, is a contentious topic. We will continue to monitor animal welfare going forward.

Four investors reported corporate engagement on the issue of AMR through involvement with the FAIRR Alliance's Global Investor Statement on Antibiotics Stewardship. ${ }^{85}$

\section{DISCUSSION}

\subsection{Motivating investors to attend to sustainable food systems}

As a desktop review, this project was designed to investigate emerging best practice. Further research, including interviews with key informants in the finance sector, would be necessary to investigate what motivates institutional investors to pay attention to some issues and not others. Our findings do suggest some hypotheses for further investigation. Other empirical research has found that investors are typically only motivated to adopt RI strategies once the short term material risk of a particular ESG factor becomes evident, or, alternatively, where enough other leading edge investors see the new factor as market relevant, invoking a 'herding' response. ${ }^{86}$ External action can make the short term material risk of particular investments apparent when new laws or regulations are imposed by government on particular industry sectors, when a particular investee businesses is subject to civil litigation or enforcement action, or when a business or sector suffers reputational damage as a result of the campaigns of civil society and NGOs that attract media attention. ${ }^{87}$ It is plausible to hypothesise from our desktop

\footnotetext{
${ }^{85}$ FAIRR, Responding to Resistance: Investor Exposure to Antibiotic Risk, and FAIRR's Engagement with the Restaurant Sector (2017).

${ }^{86}$ Justyna Przychodzen et al, 'ESG Issues among Fund Managers: Factors and Motives' (2016) 8(10) Sustainability 1078.

${ }^{87}$ See, eg, Gunningham (n 31); Ferrando (n 17); Parfitt (n 46) 74.
} 
review that investors were particularly attentive to the material risks associated with food system issues where there was external contestation by legal authorities, vocal civil society groups, and media attention that made the short term material risks of issues more evident. The two most common food system issues addressed were labour rights (mentioned by 10 investors under the human rights heading) and issues with intensive animal agriculture (10 investors). Both of these have been subject to consistent external civil society and legal action (as argued immediately below).

In relation to labour rights, civil society and media investigations into labour abuses for products like prawns from Thailand and fresh fruit and vegetables harvested by foreign workers in Australia prompted particular concern about the vulnerability of food retailers to damaging revelations about human rights abuses. ${ }^{88}$ Revelations of systemic underpayments of workers in food franchises, restaurants and cafes resulted in legal action against prominent businesses like major supermarket Woolworths and pizza chain Domino's and attracted much media attention and investor concern. ${ }^{89}$ The implementation of the new Modern Slavery Act in Australia in 2019 (and earlier in the UK) also prompted a flurry of activity by corporate advisers and ESG analysts. The Act requires businesses over a certain size to conduct 'due diligence' in order to report on the existence of modern slavery in their supply chains..$^{90}$ The mandatory disclosures generated are likely to encourage ongoing ESG attention to this issue, which appears to be endemic in the food system.

Animal welfare and AMR has been the subject of ongoing campaigning by civil society groups in relation to intensive confined animal agriculture, such as the caging of layer hens (in egg production) and use of gestation stalls and farrowing crates for sows (in ham and pork production). ${ }^{91}$ The administration of painful procedures without pain relief (such as mulesing of sheep) and the practice of live export of cattle and sheep in poor conditions onboard and with unregulated holding and slaughtering arrangements upon arrival have also garnered

\footnotetext{
${ }^{88}$ Christopher Arup, 'Enforcing Labour Standards in the Supermarket Food Supply Chain' (2019) 32(1) Australian Journal of Labour Law 103; Joanna Howe et al, 'Slicing and Dicing Work in the Australian Horticulture Industry: Labour Market Segmentation within the Temporary Migrant Workforce' (2020) 48(2) Federal Law Review 247.

${ }^{89}$ Tess Hardy, 'Trivial to Troubling: The Evolution of Enforcement under the Fair Work Act' (2020) 33(1) Australian Journal of Labour Law 87.

${ }^{90}$ Ford and Nolan (n 84).

${ }^{91}$ Parker et al, 'A Public Appetite for Poultry Welfare Regulation Reform: Why Higher Welfare Labelling Is Not Enough’ (2018) 43(4) Alternative Law Journal 238.
} 
significant media attention and, in the case of mulesing, brand boycotts. ${ }^{92}$ This has resulted in legal action or the threat of legal action to curtail or prohibit some business activities that involve particularly cruel exploitation of animals. Involvement in these activities can thus be seen as a social and governance risk. ${ }^{93}$ According to RIAA's 2020 consumer research, animal cruelty is the single top issue consumers want to avoid with their investments $(60 \%$ of consumers surveyed). ${ }^{94}$ The related question of over use of antibiotics in livestock farming (mentioned by 6 investors), which may lead to AMR, is a top priority for the World Health Organization. ${ }^{95}$ FAIRR, ${ }^{96}$ an alliance of institutional investors and animal advocacy organisations, has targeted investors to act on its ratings of listed companies on their action on AMR and other ESG issues in animal agriculture. FAIRR's campaign has garnered attention from Australian investors and financial media. ${ }^{97}$

The second mechanism for motivating investors to take new issues, such as sustainable food system themes seriously, is the 'herding' effect. We could conclude that the 'herding' response was active in this context if we could see sustainable food system issues being explicitly incorporated into metrics, benchmarks, voluntary codes, and other technical resources for ESG assessment and consideration that reflect the commitment and concerns of the RI sector as a whole. ${ }^{98}$ Many sustainable food system themes are closely connected to established ESG issues in fact, but do not seem to yet be recognised as such in commonly used metrics and resources,

\footnotetext{
92 Australia exports live sheep to the Middle East and live cattle to Asia, leading to concern among animal welfare groups and the general public about transport and slaughter conditions for the animals: $<$ https://kb.rspca.org.au/knowledge-base/what-are-the-standards-of-animal-welfare-onboard-live-export-ships/>. See also Brodie Evans and Hope Johnson, "Responding to the Problem of "Food Security" in Animal Cruelty Policy Debates' (2020) 37(1) Agriculture and Human Values 161. On mulesing see Leo Bromberg, 'Numbing the Pain or Diffusing the Pressure? The Co-optation of PETA's "Naming and Shaming" Campaign Against Mulesing' (2021) Law and Policy (in press).

${ }^{93}$ CAER, Intensive Animal Farming and Live Animal Export: Exposure of ASX Listed Companies (CAER Australia, 2017) <https://caer.com.au/wp-content/uploads/2018/05/ASX-listed-Company-Exposure-toIntensive-Animal-Farming-and-Live-Animal-Export.pdf>; FAIRR, Coller FAIRR (n 69).

${ }^{94}$ RIAA (n 57) 11 . With a further $11 \%$ wanting a negative screen on any investment in meat or meat products RIAA. (2020) From Values to Riches 2020: Charting Consumer Expectations and Demand for Responsible Investing in Australia. Sydney: Responsible Investment Association Australasia.

95 World Health Organization, Global Action Plan on Antimicrobial Resistance (2015).

${ }^{96}$ FAIRR (n 69).

${ }^{97}$ See, eg, Kristen Le Mesurier and Phoebe Jin, Is Factory Farming Making Us Sick? Human Resistance to Antibiotics: An Earnings Risk for the Global Food and Beverage Sector (AMP Capital, 2017); Adele Ferguson, 'Antibiotics the next Ethical Investment Battleground', Australian Financial Review (Sydney, online, 23 April 2017).

${ }^{98}$ MacLeod and Park (n 28); Oren Perez, 'The Green Economy Paradox: A Critical Inquiry into Sustainability Indexes’ (2016) 17 Minnesota Journal of Law, Science \& Technology 153; Weber (n 28).
} 
as is evident from our desktop review. For example, climate change is already a central concern in RI. However even though agriculture contributes $20-30 \%$ of global GHG emissions (as mentioned above), the food system was not commonly discussed in relation to climate change by the investors we reviewed. As investment in the agricultural and food sectors grows, and the impacts of climate crisis become more obvious, climate mitigation and adaptation measures for the food system are also likely to become concomitantly more important to investors. Even if institutional investors are not directly invested in agricultural producers, they are likely invested in food processing and retail businesses that will be vulnerable to climate impacts on agriculture (such as more severe and unpredictable fire, flood and drought) in their supply chains. They will also increasingly be expected to meet emissions reduction targets that take into account these agricultural supply chains. ${ }^{99}$ This is likely to have a particular impact on businesses that produce and source meat, dairy and commodity products (such as soy beans and palm oil) that have particular climate impacts through land clearing or emissions. ${ }^{100}$ Similarly ESG attention to food production's contribution to biodiversity loss (mentioned by 6 investors) is also likely to increase in attention due to the upcoming negotiations for the CBD and ongoing media attention to issues of deforestation in Australia ${ }^{101}$ and around the world. ${ }^{102}$ Both climate change and biodiversity loss are increasingly seen as issues for supply chain due diligence. That is, processing and retail companies are expected to ensure that they source products and services with minimal impact. ${ }^{103}$ Even institutional investors are expected to report on the climate and biodiversity impacts of the businesses and assets in which they invest. $^{104}$ An important potential motivator for future incorporation of food system sustainability concerns into RI is work underway by international alliances of investors and governmental bodies to consider how climate change and biodiversity are disclosed and

\footnotetext{
${ }^{99}$ See for example, Nives Dolsak and Aseem Prakash, 'Unilever's Climate Plan: Emissions from Supply Chain and Consumers are the Real Challenge' (Forbes.com, 18 June 2020)

<https://www.forbes.com/sites/prakashdolsak/2020/06/18/unilevers-climate-plan-emissions-from-supply-chainand-consumers-are-the-real-challenge/?sh=7b027f761fba>

${ }^{100}$ See eg Oliver Lazarus, Sonali McDermid and Jennifer Jacquet, 'The Climate Responsibilities of Industrial Meat and Dairy Producers' (2021) 165:30 Climatic Change (online) < https://doi.org/10.1007/s10584-02103047-7>

${ }^{101}$ Megan C Evans, 'Effective Incentives for Reforestation: Lessons from Australia's Carbon Farming Policies' (2018) 32 Current Opinion in Environmental Sustainability 38.

${ }^{102}$ Friends of the Earth Australia (n 80); WWF International (n 79).

${ }^{103}$ CDP (n 34).

${ }^{104}$ Gunningham (n 31).
} 
analysed as ESG risks, with food production a key priority. ${ }^{105}$ The SDGs are also increasingly important in new frameworks for sustainable finance. ${ }^{106}$ Although largely neglected to date, it is likely that food and agriculture will become increasingly significant, since the right to a healthy sustainable diet is central to SDG2.

\subsection{Use of different RI strategies}

The purpose of RI is not merely to manage risk and increase financial rewards for each separate institutional investor and its customers, but to influence the whole market towards greater sustainability overall. Therefore, it is important to consider not only whether investors are taking the full range of sustainable food system themes into account in their decision-making, but also whether the RI strategies they adopt actually have any impact on the investee businesses and the food system as a whole. This preliminary desktop review did not collect and analyse data that allows us to examine how effective the various RI strategies adopted were at managing risk or influencing change towards sustainable food systems. Our findings do however raise directions for further investigation into the potential for institutional investors and those they work with to influence food businesses towards more sustainable practices.

This study found that corporate engagement and shareholder action that seeks to directly influence investee company behaviour was the most popular reported RI strategy in relation to sustainable food system themes (13 investors). In Australia, this commonly occurs through direct communication with senior management or boards, and can also occur via the exercise of shareholder power by, for example, co-filing shareholder resolutions and proxy voting. ${ }^{107}$ This may be done individually or in alliance with other investors and activists or NGOs in order to achieve more systemic change. ${ }^{108}$ Alliances of investors working together (and often together with civil society experts) have been able to obtain commitments to improved sustainability performance. For example, a number of investors stated that they had joined UKbased investor alliance FAIRR (which originally stood for 'Farm Animal Investment Risk Response') coordinated investor engagements on AMR. ${ }^{109}$

\footnotetext{
${ }^{105}$ See, eg, CERES, The Investor Guide (n 33); CDP (n 34); Feedback (n 34); Matt McLuckie, Nitin Sukh and Gabriel Thoumi, Growing for Profit (Planet Tracker, 2020).

106 ASFI (n 44).

${ }^{107}$ Kym Sheehan, Shareholder Resolutions in Australia (Australian Council of Superannuation Investors, 2017).

${ }^{108}$ MacLeod and Park (n 28).

${ }^{109}$ FAIRR (n 73).
} 
Corporate engagement and action is sometimes criticised as hypocritical and ineffective where funds continue to hold investments in businesses that engage in unsustainable practices (e.g. businesses that produce palm oil from deforested areas or those that use confined animals for food production) in the hope of changing their behaviour, and that negative exclusions are therefore necessary for either strategic or ethical reasons. ${ }^{110}$ In our sample, seven investors used negative screening in relation to at least one food system theme where business practices were defined as unethical or unsustainable. Some specialist sustainable or ethical investors like AE and Stewart took an approach in which a large range of businesses were considered noninvestable. This was because they were either considered inherently unsustainable in the long term, and thus not profitable for longer term value creation, or because customers who had signed up to a specialist sustainable or ethical fund had explicitly done so in order to avoid investments that would contravene certain environmental and social values.

Some commentators argue that negative screening is not that useful if the aim is strategic, that is to influence investees towards better practices. ${ }^{111}$ This is because in a negative screening strategy, the investor divests (or does not invest at all) in the relevant stock and therefore gives up the possibility of engaging with the investee company to influence change. ${ }^{112}$ Others argue however that negative screening by boutique funds is often the 'canary in the coalmine' for business practices that eventually come to be seen as socially and legally unacceptable, and therefore risky and potentially even 'stranded assets'. ${ }^{113}$ For investors with an explicit aim of investing in line with beneficiaries' ethical concerns or for long term value creation, an investment strategy in which potentially risky businesses are excluded and only those that meet certain fundamental requirements for sustainability are included can be valuable. It is also relevant that investors who seek to influence investees via engagement and action are likely to

\footnotetext{
${ }^{110}$ See Julie Ayling and Neil Gunningham, 'Non-State Governance and Climate Policy: The Fossil Fuel Divestment Movement' (2015) Climate Policy 1; Fergus Green, 'Anti-fossil fuel norms' (2018) 150(1-2) Climatic Change 103; Luis E Hestres and Jill E. Hopke, 'Fossil Fuel Divestment: Theories of Change, Goals, and Strategies of a Growing Climate Movement' (2019) Environmental Politics 1.

${ }^{111}$ See for example, Schoenmaker and Schramade (n 18), 227 (citing research that negative screening is the most used method in RI but also perceived as less useful in terms of actually creating change than positive engagement). For a good summary of strategic arguments for and against divestment in the context of fossil fuels, see Sybille Braungardt, Jeroen van den Bergh and Tessa Dunlop, 'Fossil Fuel Divestment and Climate Change: Reviewing Contested Arguments' (2019) 50 Energy Research \& Social Science 191. See also Kate J Neville, 'Shadows of Divestment: The Complications of Diverting Fossil Fuel Finance' (2020) 20(2) Global Environmental Politics 3.

112 Neville, 'Shadows of Divestment' ibid.

113 James P Hawley, 'Setting the Scene: The Basics and Basis of Responsible Investment' in Tessa Hebb et al (eds), The Routledge Handbook of Responsible Investment (Routledge, 2015) 21.
} 
be taken more seriously if they also credibly wield the 'stick' of potential divestment as part of their engagement repertoire when repeated attempts at engagement are ignored. ${ }^{114}$ In our sample, there were some cases where investors reported that they started with engagement and then followed on with divestment or negative screening (presumably because the businesses' response to the initial engagement was unsatisfactory). Some investors also reported that they hold nominal shareholdings in otherwise excluded companies in order to support shareholder advocacy through alliances of investors and NGOs, obtaining the best of both worlds.

Only seven investors reported engaging in the systematic and explicit inclusion of ESG factors into financial valuation and selection of investments. Some investors (Stafford, Stewart) emphasised that they preferred in depth consideration of each investee business on its own terms (often referred to as 'fundamental' or 'active' RI, as opposed to 'passive' RI by means of metrics and indexes to weight the selection of stock). Marshalling complex ESG considerations into quantifiable metrics can oversimplify complex considerations and predispose towards greenwashing. ${ }^{115}$ However, developing such benchmarks and metrics for ESG integration is a core aspect of RI, and sustainable food system themes are unlikely to be taken seriously until such metrics and benchmarks exist and are promoted (as mentioned above in relation to 'herding'). Nevertheless, metrics are unlikely to be effective on their own and indepth corporate engagement and shareholder action is generally considered a necessary partner to ESG integration, with ESG integration often referring to how the portfolio is constructed while engagement and action refers to the investor actively using their voice once they have invested.

The paucity of reports of positive and best in class screening in our sample (only 3 investors) and lack of any reports of norms-based screening may reflect the immaturity of metrics and benchmarks in relation to food systems and ESG driven investment. It is also not surprising that our sample did not capture much in the way of impact investing focused on food (2 investors) because our samples focused mainly on large institutional investors rather than private capital firms, which are perhaps more likely to focus on impact investing. Nevertheless, RIAA benchmarking indicates that investment in sustainable agriculture is a popular focus for

\footnotetext{
${ }^{114}$ Neil Gunningham, Neil, 'Review Essay: Divestment, Nonstate Governance, and Climate Change' (2017) 39(4) Law \& Policy 309.

${ }^{115}$ Perez (n 86); Jay Cullen and Jukka Tapio Mähönen, 'Taming Unsustainable Finance: The Perils of Modern Risk Management' in Beate Sjafjell and CM Bruner (eds), The Cambridge Handbook of Corporate Law, Corporate Governance and Sustainability (Cambridge University Press, 2019) 100.
} 
growing interest in impact investing and sustainability-themed investing in Australia. ${ }^{116}$ Seven investors in our sample did refer to sustainability-themed investing in relation to sustainable food system themes with some mentioning plans to invest in sustainable or climate resilient agriculture but often in a fairly generic way. The lack of benchmarks and metrics is problematic in this area. There is little guidance or common understanding as to what counts as sustainable food broadly from agricultural production to diet — but much hope that land and farming can be used for carbon offsetting for meeting Paris Accord climate targets and sustainable agriculture more broadly in terms of SDG targets. ${ }^{117}$ Care will be needed to evaluate whether these investments in 'sustainable agriculture' do in fact lead to more sustainable food systems or whether it is more likely to encourage greenwashing and further financialisaton of the food system with consequent negative impacts on land, farmers and the availability and price of healthy sustainable food. ${ }^{118}$

A limitation of our desktop review was that it took a snapshot of individual RI strategies reported at one moment in time. However, investors may apply multiple investment strategies sequentially and concurrently during investment and decision-making processes. More indepth study of how investors use different RI strategies over time with different investee companies would be necessary to fully understand how effectively RI can be used to transform business practices. Furthermore, many of the investors in this sample apply their approach to RI in different ways for different funds and different customers. In particular many have an ethical or sustainable fund that excludes certain businesses only for beneficiaries who have explicitly requested that fund. However these institutional investors do not adopt an RI approach for their other funds and beneficiaries for fear that it might be in breach of their fiduciary obligation to maximise the financial interest of beneficiaries. ${ }^{119}$ The urgent global

\footnotetext{
116 RIAA (n 61).

117 James Temple, 'Why We Can't Count on Carbon-Sucking Farms to Slow Climate Change' [2020] MIT Technology Review.

${ }^{118}$ Clapp and Isakson, Speculative Harvests (n 14); Larder et al (n 14); Ferrando (n 17).

119 This is because superannuation and managed investment funds are trusts for the benefit of retail investors. Institutional investors as trustees for their customer-beneficiaries have fiduciary duties to act only in the benefit of those who have invested funds with them. For a useful summary see Brett McDonnell, Hari M Osofosky, Jacqueline Peel and Anita Foerster, 'Green Boardrooms?' (2020) Connecticut Law Review, forthcoming, at 915. Available at SSRN: https://ssrn.com/abstract=3569303 For a more comprehensive discussion of the arguments and considerations in the US context, see Max Schanzenbach and Robert H Sitkoff, 'Reconciling Fiduciary Duty and Social Conscience: The Law and Economics of ESG Investing by a Trustee' (2020) 72 Stanford Law Review, pp 381-484. In practice, however, ESG integration is generally justified as in the financial interests of companies, shareholders, investors and beneficiaries at least in the longer term if not the short term.
} 
issues facing the food system will require action by every sector of society, including the finance sector. It is therefore vital to further investigate what this should entail in terms of actions by investors and any legal and policy changes necessary to support appropriate action. While this paper focused only on Australian institutional investors, a global view is necessary. In particular, a small number of large-scale asset managers (based in the US) are significant shareholders in some of the largest global food sector companies. ${ }^{120}$ These large-scale global asset managers are likely to hold considerable influence over the food and agriculture industry.

\section{CONCLUSION}

There is increasing recognition of the need for a holistic 'food systems' approach to underpin global efforts to promote sustainable food systems. ${ }^{121}$ Integrated food systems approaches ${ }^{122}$ recognise the links between individual sustainable food issues and the potential for achieving multiple co-benefits by taking action to address problematic practices. Integrated food systems approaches also enable consideration of the tensions and trade-offs involved in taking action on individual food system issues. The food systems approach also recognises that many actors, including producers, consumers, governments and finance sector actors all have different interacting capacities to shape the direction of food systems into the future. This makes it important to further investigate finance sector actors and their impact on sustainable food systems.

However, the extent to which institutional investors use RI strategies to address the interconnected ESG challenges raised by investment in food systems has received little attention in academic research. The findings from this desk-based review indicate that some institutional investors in Australia are identifying ESG issues related to sustainable food system themes, albeit in a limited way. Some 'hot' issues are being addressed by some best practice responsible investors, but an holistic consideration of how to invest to promote socially,

See PRI, UNEP FI and The Generation Foundation, Fiduciary Duty in the $21^{\text {st }}$ Century: Australia Roadmap (UN PRI, 2016), available at https://www.unpri.org/fiduciary-duty/fiduciary-duty-in-the-21st-century-australiaroadmap/258.article (accessed 25 January 2021).

120 Jennifer Clapp, 'The Rise of Financial Investment and Common Ownership in Global Agrifood Firms' (2019) 26(4) Review of International Political Economy 604.

${ }^{121}$ UNEP, Collaborative Framework for Food Systems Transformation: A Multi-Stakeholder Pathway for Sustainable Food Systems. (One Planet Network Sustainable Food Systems Programme. United Nations Environment Programme., 2019) <https://www.oneplanetnetwork.org/sites/default/files/une_collaborative_framework_for_food_systems_transformation_final.pdf $>$.

122 See, eg, HLPE, Food Security and Nutrition: Building a Global Narrative Towards 2030 (High Level Panel of Experts on Food Security and Nutrition of the Committee on World Food Security, 2020). 
ecologically and economically sustainable food systems was extremely rare. The extent to which publicly reported commitment to use RI strategies to address food systems issues actually translates into consistent investment decisions, and the impact this has on business practices in the food sector warrants further critical investigation. Our research suggests that there is a lack of indicators and metrics for specific issues, and none at all for holistic food systems perspectives. Some alliances of civil society groups and responsible investors are beginning to work on these issues. International public and private governance institutions are also beginning to pay attention to the nexus of investment and sustainable healthy food systems. These developments are likely to encourage greater consideration of these issues, but this may also lead to the danger of 'greenwashing' RI responses.

Further empirical research is needed to inform civil society groups and responsible investor alliances as to how different investment strategies might be strategically used in combination to help move food systems towards greater sustainability. In particular, further understanding of investors' motivations for consideration of food system sustainability, and what information and policy actions might motivate more serious attention to food system sustainability themes is needed. Further legal and policy analysis is also necessary to identify policies and governance strategies to advance financial investment that promotes sustainable food systems. These might include the development of industry codes and metrics to guide investment in the food system, mandatory consideration and reporting of ESG considerations in investing (and the modification of laws that prevent such considerations), regulation of accuracy in reporting according to more independent and accountable metrics, and public investment in food and agriculture infrastructure for the ecologically sustainable production of the healthy food necessary for basic food security. ${ }^{123}$

\footnotetext{
${ }^{123}$ For policy suggestions about the need for production and provision of fresh fruit and vegetables close to major population areas and on the ground or online infrastructure for fresh food markets to distribute them, see Rachel Carey, Kirsten Larsen \& Jennifer Sheridan, Roadmap for a Resilient and Sustainable Melbourne Foodbowl (Foodprint Melbourne, The University of Melbourne, 2019) < $10.26188 / 5$ c92e85dd6edf $>$
} 


\section{APPENDIX: METHODS}

Table A1: Characteristics of asset managers and superannuation funds included in the sample

\begin{tabular}{|c|c|c|}
\hline & $\begin{array}{l}\text { Type of fund }{ }^{124} \\
\text { (applicable only to super } \\
\text { funds) }\end{array}$ & $\begin{array}{l}\text { Total assets under } \\
\text { management }^{125} \\
\text { (AUD billion) }\end{array}$ \\
\hline \multicolumn{3}{|c|}{$\begin{array}{l}\text { Asset Managers } \\
\text { (Abbreviation used in Table } 3 \text { and discussion of results shown in brackets }{ }^{126} \text { ) }\end{array}$} \\
\hline AMP Capital ('AMP') & & $\$ 187.25$ \\
\hline $\begin{array}{l}\text { Ausbil Investment } \\
\text { Management ('Ausbil') }\end{array}$ & & $\$ 10.48$ \\
\hline $\begin{array}{l}\text { Australian Ethical } \\
\text { Investment ('AE') }\end{array}$ & & $\$ 2.82$ \\
\hline $\begin{array}{l}\text { Dexus Property Group } \\
\text { ('Dexus') }\end{array}$ & & $\$ 27.20$ \\
\hline $\begin{array}{l}\text { First Sentier Investors } \\
\text { ('Sentier') }\end{array}$ & & $\$ 204.19$ \\
\hline IFM Investors ('IFM') & & $\$ 117.09$ \\
\hline $\begin{array}{l}\text { Investa Property Group } \\
\text { ('Investa') }\end{array}$ & & $\$ 11.00$ \\
\hline $\begin{array}{l}\text { Lendlease Investment } \\
\text { Management ('Lendlease') }\end{array}$ & & $\$ 33.00$ \\
\hline $\begin{array}{l}\text { Magellan Asset } \\
\text { Management ('Magellan') }\end{array}$ & & $\$ 45.50$ \\
\hline Maple-Brown Abbot & & $\$ 14.34$ \\
\hline Mercer Australia ('Mercer') & & $n / a$ \\
\hline Pendal & & $\$ 92.82$ \\
\hline $\begin{array}{l}\text { Pengana Capital Group } \\
\text { ('Pengana') }\end{array}$ & & $\$ 3.01$ \\
\hline $\begin{array}{l}\text { Perpetual Investments } \\
\text { ('Perpetual') }\end{array}$ & & $\$ 30.80$ \\
\hline QIC & & $\$ 85.01$ \\
\hline $\begin{array}{l}\text { RARE Infrastructure } \\
\text { ('RARE') }\end{array}$ & & $\$ 3.53$ \\
\hline $\begin{array}{l}\text { Realindex Investments } \\
\text { ('Realindex') }\end{array}$ & & $n / a$ \\
\hline $\begin{array}{l}\text { Resolution Capital } \\
\text { ('Resolution') }\end{array}$ & & $\$ 7.78$ \\
\hline
\end{tabular}

124 This categorization is only applicable to superannuation funds as asset managers offer various retail funds. For super funds the categories are:

Retail funds $=$ for profit, owned by financial institutions, offered to the public.

Industry funds = not for profit; traditionally focused on a single industry; often co-owned by employers and unions in that industry. Some still have restrictions on membership, but many are now marketed more widely. Focus industry is shown in table (where relevant).

Public sector funds $=$ not for profit funds, established for government sector employees by government agencies or businesses, generally available only to public sector employees.

125 As at 2018, from PRI Transparency Reports (2019), unless otherwise indicated. Available at: <https://www.unpri.org/signatories/transparency-reports-2019/4506>. Total assets under management includes subsidiaries and excludes advisory/execution only assets.

${ }^{126}$ If no abbreviation is provided that is either because the investor did not appear in our results as explicitly discussing any sustainable food system theme, or because we used their whole name (eg Pendal, CareSuper, . 


\begin{tabular}{|c|c|c|}
\hline $\begin{array}{l}\text { Solaris Investment } \\
\text { Management ('Solaris') }\end{array}$ & & $\$ 7.61$ \\
\hline $\begin{array}{l}\text { Stafford Capital Partners } \\
\text { ('Stafford') }\end{array}$ & & $\$ 4.86$ \\
\hline $\begin{array}{l}\text { Stewart Investors }{ }^{127} \\
\text { ('Stewart') }\end{array}$ & & $n / a$ \\
\hline $\begin{array}{l}\text { U Ethical Funds } \\
\text { Management ('U Ethical') }\end{array}$ & & $\$ 1.12$ \\
\hline $\begin{array}{l}\text { Uniting Financial Services } \\
\text { ('Uniting') }\end{array}$ & & $\$ 1.63$ \\
\hline $\begin{array}{l}\text { Wavestone Capital } \\
\text { ('Wavestone') }\end{array}$ & & $\$ 3.90$ \\
\hline \multicolumn{3}{|l|}{ Superannuation funds } \\
\hline Australian Ethical ('AE') & Retail - Ethical focus & $\$ 2.82$ \\
\hline AustralianSuper & $\begin{array}{l}\text { Industry - Default fund for all } \\
\text { industries (largest super fund } \\
\text { in Australia) }\end{array}$ & $\$ 142.19$ \\
\hline CareSuper ('Care') & $\begin{array}{l}\text { Industry - Professional and } \\
\text { service industries }\end{array}$ & $\$ 14.76$ \\
\hline Cbus & $\begin{array}{l}\text { Industry -Building \& } \\
\text { construction }\end{array}$ & $\$ 46.69$ \\
\hline Christian Super ('Christian') & $\begin{array}{l}\text { Industry - Christian } \\
\text { community schools } \\
\text { Ethical and impact focus }\end{array}$ & $\$ 1.42$ \\
\hline $\begin{array}{l}\text { First State Super ('First } \\
\text { State') }\end{array}$ & $\begin{array}{l}\text { Public - originally for } \\
\text { government employees in } \\
\text { NSW only, later merged with } \\
\text { health and teaching funds }\end{array}$ & $\$ 70.56$ \\
\hline Future Super ('Future') & $\begin{array}{l}\text { Retail } \\
\text { Environmental sustainability } \\
\text { focus }\end{array}$ & $\$ 0.34^{128}$ \\
\hline HESTA & $\begin{array}{l}\text { Industry - health and } \\
\text { community services }\end{array}$ & $\$ 46.87$ \\
\hline $\begin{array}{l}\text { Local Government Super } \\
\text { ('LG') }\end{array}$ & $\begin{array}{l}\text { Public - local government } \\
\text { employees }\end{array}$ & $\$ 7.79$ \\
\hline UniSuper & $\begin{array}{l}\text { Industry - higher education } \\
\text { and research }\end{array}$ & $\$ 70.54$ \\
\hline VicSuper $^{129}$ & Public - public sector & $\$ 21.21$ \\
\hline Vision Super ('Vision') & Public - community sector & $\$ 9.65$ \\
\hline
\end{tabular}

${ }^{127}$ RealIndex Investments and Stewart Investors are subsidiaries of First Sentier Investors. and as such their AUM is included within First Sentier Investors.

${ }^{128}$ As at June 2018, from Future Super Annual Report (2018).

${ }^{129}$ VicSuper merged with First State Super as of 1 July 2020. 
Table A2: Definitions and Coding Strategies for Sustainable Food System Themes ${ }^{130}$

\begin{tabular}{|c|c|c|}
\hline Key Themes & Definitions & Coding Criteria \\
\hline $\begin{array}{l}\text { Climate } \\
\text { Change }\end{array}$ & $\begin{array}{l}\text { Greenhouse gas emissions from } \\
\text { the food system including land } \\
\text { use change. }\end{array}$ & $\begin{array}{l}\text { Must specifically mention climate change } \\
\text { with respect to some aspect of food and } \\
\text { agriculture } \\
\text { - Livestock farming if specifically mentioned } \\
\text { as a climate change issue } \\
\text { - } \begin{array}{l}\text { Deforestation if specifically mentioned as } \\
\text { attributable to food production and as a } \\
\text { climate change issue } \\
\text { - Can include mentions of impact of climate } \\
\text { change on agricultural productivity (e.g. crop } \\
\text { reduction) }\end{array} \\
\end{array}$ \\
\hline Biodiversity & $\begin{array}{l}\text { Biodiversity loss attributable to } \\
\text { deforestation and land use change } \\
\text { for agriculture (overlaps with } \\
\text { climate change), over-fishing, } \\
\text { pesticide use and management of } \\
\text { genetically modified organisms. }\end{array}$ & $\begin{array}{l}\text { - Terrestrial and aquatic extinction including } \\
\text { via over-fishing and deforestation (especially } \\
\text { palm oil and soy plantations) } \\
\text { - Land and soil degradation, including } \\
\text { pesticide use } \\
\text { - } \text { GMO management }\end{array}$ \\
\hline Water & $\begin{array}{l}\text { Use of water in agricultural } \\
\text { production and food processing; } \\
\text { and risk of water scarcity } \\
\text { (overlaps with climate change). }\end{array}$ & $\begin{array}{l}\text { Does not include fishing, aquaculture, } \\
\text { impact on oceans and freshwater rivers, } \\
\text { water ways etc (included in Biodiversity } \\
\text { Loss(above) } \\
\text { Only if water use is mentioned specifically in } \\
\text { relation to food production including cotton } \\
\text { (which is used for cotton seed oil) }\end{array}$ \\
\hline $\begin{array}{l}\text { Food loss } \\
\text { and waste }\end{array}$ & $\begin{array}{l}\text { Adoption of initiatives to reduce } \\
\text { food loss and waste throughout } \\
\text { the food supply chain. }\end{array}$ & $\begin{array}{l}\text { - Issues concerning the management of food } \\
\text { waste (reusing, reducing, closed-loop } \\
\text { systems etc) }\end{array}$ \\
\hline $\begin{array}{l}\text { Human } \\
\text { rights }\end{array}$ & $\begin{array}{l}\text { Human rights relating to labour } \\
\text { rights (modern slavery } \\
\text { obligations, underpayment and } \\
\text { other fair labour practices), land } \\
\text { rights and Indigenous rights. }\end{array}$ & $\begin{array}{l}\text { - Any human rights issues if specifically } \\
\text { related to the food supply chain or to food } \\
\text { businesses } \\
\text { - Labour rights, modern slavery, labour pay } \\
\text { and conditions } \\
\text { - Land rights, Indigenous rights }\end{array}$ \\
\hline $\begin{array}{l}\text { Animal } \\
\text { welfare and } \\
\text { antimicrobial } \\
\text { resistance } \\
\text { (AMR) }\end{array}$ & $\begin{array}{l}\text { Animal welfare and animal } \\
\text { cruelty in animal agriculture and } \\
\text { aquaculture for food. } \\
\text { Over-use of antibiotics in animal } \\
\text { agriculture and aquaculture } \\
\text { creating risk of antimicrobial } \\
\text { resistance with harm to human or } \\
\text { animal health. }\end{array}$ & $\begin{array}{l}\text { Must specifically mention animal welfare or } \\
\text { animal cruelty } \\
\text { - Other environmental and social concerns } \\
\text { with animal agriculture to be coded in other } \\
\text { appropriate categories } \\
\text { - Includes concerns with live export of } \\
\text { animals overseas } \\
\text { - Issues with use of antibiotics in animal and } \\
\text { fish farming }\end{array}$ \\
\hline
\end{tabular}

${ }^{130}$ Adapted from Nicholson, Plating Up Progress: Part 2 (n 37); Nicholson, Plating Up Progress: Pathways (n $37)$. 


\begin{tabular}{|c|c|c|}
\hline $\begin{array}{l}\text { Sustainable } \\
\text { food } \\
\text { production } \\
\text { practices }\end{array}$ & $\begin{array}{l}\text { Adoption of approaches to } \\
\text { promote environmentally (and } \\
\text { socially) sustainable agriculture. } \\
\text { Also includes issues related to } \\
\text { sustainable food production not } \\
\text { captured by the categories above. }\end{array}$ & $\begin{array}{l}\text { - Includes generic mentions of "sustainable } \\
\text { agriculture" and similar terms e.g. } \\
\text { "regenerative agriculture" } \\
\text { - Any other issues specifically related to } \\
\text { socially and environmentally sustainable } \\
\text { food production not covered in the categories } \\
\text { above }\end{array}$ \\
\hline
\end{tabular}


Table A3: Responsible investment strategies, definitions and criteria for coding

\begin{tabular}{|c|c|c|}
\hline $\begin{array}{c}\text { Responsible } \\
\text { investment strategy }\end{array}$ & Definition $^{131}$ & Coding Criteria \\
\hline $\begin{array}{l}\text { 1. Negative/ } \\
\text { exclusionary } \\
\text { screening }\end{array}$ & $\begin{array}{l}\text { Screening that systematically } \\
\text { excludes specific sectors, } \\
\text { companies or practices based on } \\
\text { ESG criteria e.g. gambling, } \\
\text { alcohol, tobacco, weapons, } \\
\text { pornography and animal testing. }\end{array}$ & $\begin{array}{l}\text { - Specifically referred to as 'negative' or } \\
\text { 'exclusionary' 'screening' } \\
\text { - Must systematically apply exclusion to } \\
\text { specific types of companies or sectors } \\
\text { - One off or temporary exclusions are } \\
\text { not counted here, but may be } \\
\text { categorised as ESG integration }\end{array}$ \\
\hline $\begin{array}{l}\text { 2. Positive/best-in- } \\
\text { class screening }\end{array}$ & $\begin{array}{l}\text { Inclusion of sectors, companies } \\
\text { or projects based on positive } \\
\text { ESG or sustainability } \\
\text { performance relative to industry } \\
\text { peers. }\end{array}$ & $\begin{array}{l}\text { - Specifically referred to as 'positive' or } \\
\text { 'best-in-class' screening } \\
\text { - Performance compared to peers but } \\
\text { using a defined method (e.g. through a } \\
\text { benchmark) }\end{array}$ \\
\hline $\begin{array}{l}\text { 3. Norms-based } \\
\text { screening }\end{array}$ & $\begin{array}{l}\text { Screening of investments that do } \\
\text { not meet minimum standards of } \\
\text { business practice, based on } \\
\text { international norms and } \\
\text { conventions (e.g. those from the } \\
\text { United Nations). May result in } \\
\text { exclusion of assets that } \\
\text { contravene these norms and } \\
\text { conventions, or inclusion of } \\
\text { assets that uphold them. }\end{array}$ & $\begin{array}{l}\text { Specifically referred to as 'norms- } \\
\text { based screening' } \\
\text { Refers to an international convention, } \\
\text { framework or body in relation to } \\
\text { screening strategy }\end{array}$ \\
\hline 4. ESG integration & $\begin{array}{l}\text { Systematic and explicit } \\
\text { inclusion of ESG factors into } \\
\text { traditional financial analysis and } \\
\text { investment decision-making. }\end{array}$ & $\begin{array}{l}\text { - Specifically referred to as 'integration } \\
\text { of ESG factors' or 'ESG integration' } \\
\text { - Discussion of risks and opportunities } \\
\text { in relation to ESG issues } \\
\text { - Inclusion of ESG issues into the } \\
\text { decision-making process }\end{array}$ \\
\hline $\begin{array}{l}\text { 5. Sustainability- } \\
\text { themed investing }\end{array}$ & $\begin{array}{l}\text { Investment in themes or assets } \\
\text { that specifically relate to } \\
\text { improving social and/or } \\
\text { environmental sustainability e.g. } \\
\text { funds that invest in clean } \\
\text { energy, green technology, } \\
\text { sustainable agriculture and } \\
\text { forestry, or green property. }\end{array}$ & $\begin{array}{l}\text { - Refers specifically to 'sustainability- } \\
\text { themed' investments } \\
\text { - Investments are targeted towards } \\
\text { sustainability-themed companies or } \\
\text { industries, or solves particular } \\
\text { sustainability challenges }\end{array}$ \\
\hline
\end{tabular}

\footnotetext{
${ }^{131}$ Adapted from the classification and definitions adopted in RIAA's Responsible Investment Benchmark Report 2019 (Thompson and Bayes (n 29), which is in turn based on the classification of RI strategies by Eurosif, European SRI Study 2018 (Eurosif, 2018) <http://www.eurosif.org/wpcontent/uploads/2018/11/European-SRI-2018-Study.pdf> and GSIA (n 26).
} 


\begin{tabular}{|c|c|c|}
\hline $\begin{array}{l}\text { 6. Impact and } \\
\text { community } \\
\text { investing }\end{array}$ & $\begin{array}{l}\text { Impact investing includes } \\
\text { targeted investment aimed at } \\
\text { addressing social or } \\
\text { environmental issues whilst also } \\
\text { creating positive financial } \\
\text { returns. Community investing } \\
\text { includes investment in } \\
\text { underserved individuals or } \\
\text { communities, and also } \\
\text { businesses with a social and } \\
\text { environmental purpose. }\end{array}$ & $\begin{array}{l}\text { - Refers specifically to impact on a } \\
\text { community or a particular cause } \\
\text { - Investment in specific community } \\
\text { projects }\end{array}$ \\
\hline $\begin{array}{l}\text { 7. Corporate } \\
\text { engagement and } \\
\text { shareholder action }\end{array}$ & $\begin{array}{l}\text { The employment of shareholder } \\
\text { power to influence corporate } \\
\text { behaviour in relation to ESG } \\
\text { issues. This may occur through } \\
\text { direct corporate engagement } \\
\text { such as communications with } \\
\text { senior management or boards, or } \\
\text { filing or co-filing shareholder } \\
\text { proposals and proxy voting. }\end{array}$ & $\begin{array}{l}\text { - } \\
\text { - } \quad \text { Proxy voting } \\
\text { - } \text { Advocacy directed at company } \\
\text { management }\end{array}$ \\
\hline
\end{tabular}




\section{University Library}

\section{- M M N E R VA A gateway to Melbourne's research publications}

Minerva Access is the Institutional Repository of The University of Melbourne

Author/s:

Parker, C;Carey, R;Boehm, L;Sacks, G;Robinson, E

Title:

Responsible investing for food system sustainability: A review of current practice in Australia

Date:

2021

Citation:

Parker, C., Carey, R., Boehm, L., Sacks, G. \& Robinson, E. (2021). Responsible investing for food system sustainability: A review of current practice in Australia. Environmental and Planning Law Journal, 38 (3), pp.237-262

Persistent Link:

http://hdl.handle.net/11343/276980 